\title{
Energy Conversion and Transmission Characteristics Analysis of Ice Storage Air Conditioning System Driven by Distributed Photovoltaic Energy System
}

\author{
Yongfeng Xu, ${ }^{1,2}$ Ming Li, ${ }^{1}$ and Reda Hassanien Emam Hassanien ${ }^{1,3}$ \\ ${ }^{1}$ Solar Energy Research Institute, Yunnan Normal University, Kunming, Yunnan 650500, China \\ ${ }^{2}$ Zhejiang Solar Energy Product Quality Inspection Center, Haining, Zhejiang 314416, China \\ ${ }^{3}$ Agricultural Engineering Department, Faculty of Agriculture, Cairo University, Cairo 12613, Egypt \\ Correspondence should be addressed to Ming Li; lmllly@126.com
}

Received 4 June 2016; Accepted 20 September 2016

Academic Editor: Alessandro Burgio

Copyright ( 2016 Yongfeng Xu et al. This is an open access article distributed under the Creative Commons Attribution License, which permits unrestricted use, distribution, and reproduction in any medium, provided the original work is properly cited.

\begin{abstract}
In order to reduce the investment and operation cost of distributed PV energy system, ice storage technology was introduced to substitute batteries for solar energy storage. Firstly, the ice storage air conditioning system (ISACS) driven by distributed photovoltaic energy system (DPES) was proposed and the feasibility studies have been investigated in this paper. And then, the theoretical model has been established and experimental work has been done to analyze the energy coupling and transferring characteristics in light-electricity-cold conversion process. In addition, the structure optimization analysis was investigated. Results revealed that energy losses were high in ice making process of ice slide maker with only $17.38 \%$ energy utilization efficiency and the energy efficiency and exergy efficiency of ISACS driven by DPES were $5.44 \%$ and $67.30 \%$, respectively. So the immersed evaporator and cointegrated exchanger were adopted for higher energy utilization efficiency and better financial rewards in structure optimization. The COP and exergy efficiency of ice maker can be increased to 1.48 and $81.24 \%$, respectively, after optimization and the energy utilization efficiency of ISACS driven by DPES could be improved 2.88 times. Moreover, ISACS has the out-of-the-box function of ordinary air conditioning system. In conclusion, ISACS driven by DPES will have good application prospects in tropical regions without power grid.
\end{abstract}

\section{Introduction}

With the dramatic climate changes, the cooling demand has been increased and led to a rapid growth of energy consumption, which causes traditional fossil fuel energy shortage and great damage to climate and environment with the emissions of $\mathrm{CO}_{2}$ and harmful particles by extensive use of traditional fossil energy. Furthermore, a large number of the uses of the electric air conditioning can increase the tense situation between power supply of grid and demands of people. Therefore, refrigeration driven by solar energy becomes one of the promising approaches to reduce or partially replace the conventional refrigeration systems. Solar thermal refrigeration and solar photovoltaic refrigeration are two main working modes $[1,2]$. Several studies have been conducted about different solar refrigeration options in the last years for the improvement and development of solar thermal refrigeration system such as operation efficiency and operating stability [3-10]. Compared to the solar thermal refrigeration, solar photovoltaic (PV) refrigeration has more advantages on refrigerating effect, stable operation, and energy utilization rate. Along with the decrease of the investment and operation cost and the gradual increase of the conversion efficiency of PV module, the photovoltaic refrigeration will be developed rapidly.

There are two refrigeration models: thermoelectric refrigeration and vapor compression refrigeration can be driven by PV. As early as 2003, Dai et al. [11] researched thermoelectric refrigerator driven by solar cells and the results showed that the system has $0.3 \mathrm{COP}$ and the refrigerator temperature could maintain $5^{\circ} \mathrm{C} 10^{\circ} \mathrm{C}$. Due to the limitation of the working principle, thermoelectric refrigerator is only suitable 
for cold storage and cannot be used for freezing. So vapor compression refrigeration driven by PV caught researchers' attention.

Firstly, Aktacir [12] designed a multifunctional PV refrigerator and found that when indoor and outdoor average temperatures were $26.3^{\circ} \mathrm{C}$ and $24.9^{\circ} \mathrm{C}$, the minimum temperature of the refrigerator reached $-10.6^{\circ} \mathrm{C}$. The research results showed that the refrigeration efficiency of the system needed to be improved. In order to improve PV refrigeration performance, Mba et al. [13] used MATLAB software to simulate PV refrigeration system operating process and analysis system operating characteristics in different conditions. The structure optimization and the great operation scheme of the system were mentioned in the research results. Furthermore, Tina and Grasso [14] designed a software program for monitoring and managing stand-alone PV refrigerator system in a remote area, which had a real-time monitor running status and automatically recorded data feeding back to the terminal equipment. The research work can provide references for the system operation stability and optimization. It was also reported that the required photovoltaic panel area of a solar electric-vapor compression refrigeration system increases as the evaporating temperature decreases and the coefficient of the performance variation of the cooling system decreases with the decrease of evaporating temperature which can provide an important reference on the structure optimization of PV refrigerator [15]. So in the investigation on the structure optimization of PV refrigeration, Kaplanis and Papanastasiou [16] improved the performance of a traditional refrigerator driven by PV through the structure rebuild and the performance of the optimized refrigerator could be improved greatly. In addition, in order to improve the operation stability of the PV refrigerator and reduce the cost of inverter, the AC compressor was replaced by DC compressor in the research work led by Ekren et al. [17]. The result showed that PV module conversion efficiency has a greater impact on the system exergy efficiency. Finally, for the comprehensive performance of PV refrigerator such as the energy conversion, management, and operation performance, powered on three conditions such as photovoltaic components, battery, and outage system, the results showed that the system COP gradually decreases from morning till night [18].

According to comprehensive analysis, PV refrigeration system research is currently mainly concentrated on ice maker driven by PV. Batteries are essential component to store energy and to solve the intermittency of solar energy in PV refrigeration system. However, the use of batteries can increase the investing and running costs. So the PV refrigeration without batteries or batteries replacement technology was investigated. Axaopoulos and Theodoridis [19] designed a PV Ice maker without battery and studied its performance when the compressor operating efficiency was 9.2\%; they found that this prototype has a good ice making capability and reliable operation as well as a great improvement in the startup characteristics of the compressors, which remain working even during days with low solar irradiation of $150 \mathrm{~W} / \mathrm{m}^{2}$. But the refrigeration efficiency needed to be improved. The American SOLUS Refrigeration Company has developed a photovoltaic DC refrigerator substituting battery with water-propylene/ethylene glycol phase change material to store cold and reduce the system investing and running cost. Results revealed that the temperature inside the refrigerator was remaining stable at around $1.4^{\circ} \mathrm{C}$ when environment temperature was $32^{\circ} \mathrm{C}$ [20]. But the use of the water-propylene/ethylene glycol phase change material in the system increased the cost. Thus, the ice storage technology, stable performance, low cost, and large phase change latent heat have attracted researchers' attention. Ice storage technology has a great role in saving building energy, transferring peak power to off-peak, improving grid load rate, and other aspects.

The performances of ice storage were analyzed. $\mathrm{Pu}$ et al. [21] analyzed the effect of incorporating the ice thermal storage air conditioning system in power supply based on the cumulative exergy analysis method. They found that the total cumulative exergy consumption increased as the ice thermal storage (ITS) system applied. However, the average cumulative exergy variation decreased slightly as the cooling load of the ITS system increased. And then, the ice thermal energy storage (ITES) air conditioning system incorporating a phase change material (PCM) was analyzed from energy, exergy, economic, and environmental aspects [22]. Results showed that the electricity consumption of hybrid system was $6.7 \%$ and $17.1 \%$ lower than that of the simple ITES (without PCM) system and the conventional system, respectively. The economic performance of ITES was analyzed by Sanaye and Shirazi [23]. The results revealed that the amounts of electricity consumption and $\mathrm{CO}_{2}$ emission of ITS system were lower $9 \%$ and $9.8 \%$, respectively, in comparison with those of a conventional system. Furthermore, the payback period of ITS system for extra capital cost was 3.43 years. Because the ITS had superior economic performance, the ITS was widely used in the large building cooling system throughout the world. Han et al. [24] conducted an analysis study to compare between the potential impacts of ice storage systems on loadshifting under a new credit-based incentive scheme and the existing incentive arrangement in Jiangsu, China. Results indicated that adopting different schemes of ice storage can make distinct impacts on load-shifting. Wang and Dennis [25] conducted an investigation for influencing factors on the energy saving performance of battery storage and phase change cold storage in a PV cooling system with TRNSYS in three distinct climates (Madrid, Shanghai, and Brisbane). Results showed that the $\mathrm{CO}_{2}$ clathrate hydrate was the best performing cold store and this approach provided credible savings compared to a system without energy storage.

According to the above analysis, nowadays, the research and utilization of PV refrigeration and ice storage are relatively independent. In order to integrate the advantages of the two technologies together, the ice storage air conditioning system (ISACS) driven by distributed photovoltaic energy system (DPES) was established based on our previous research results [26]. This is the first time that the ice storage technology was employed in the PV system to substitute or partly replace batteries for the solar energy storage. As you know, it is clear that the tropical regions, such as Xishuangbanna in China and Bangkok in Thailand, have almost 


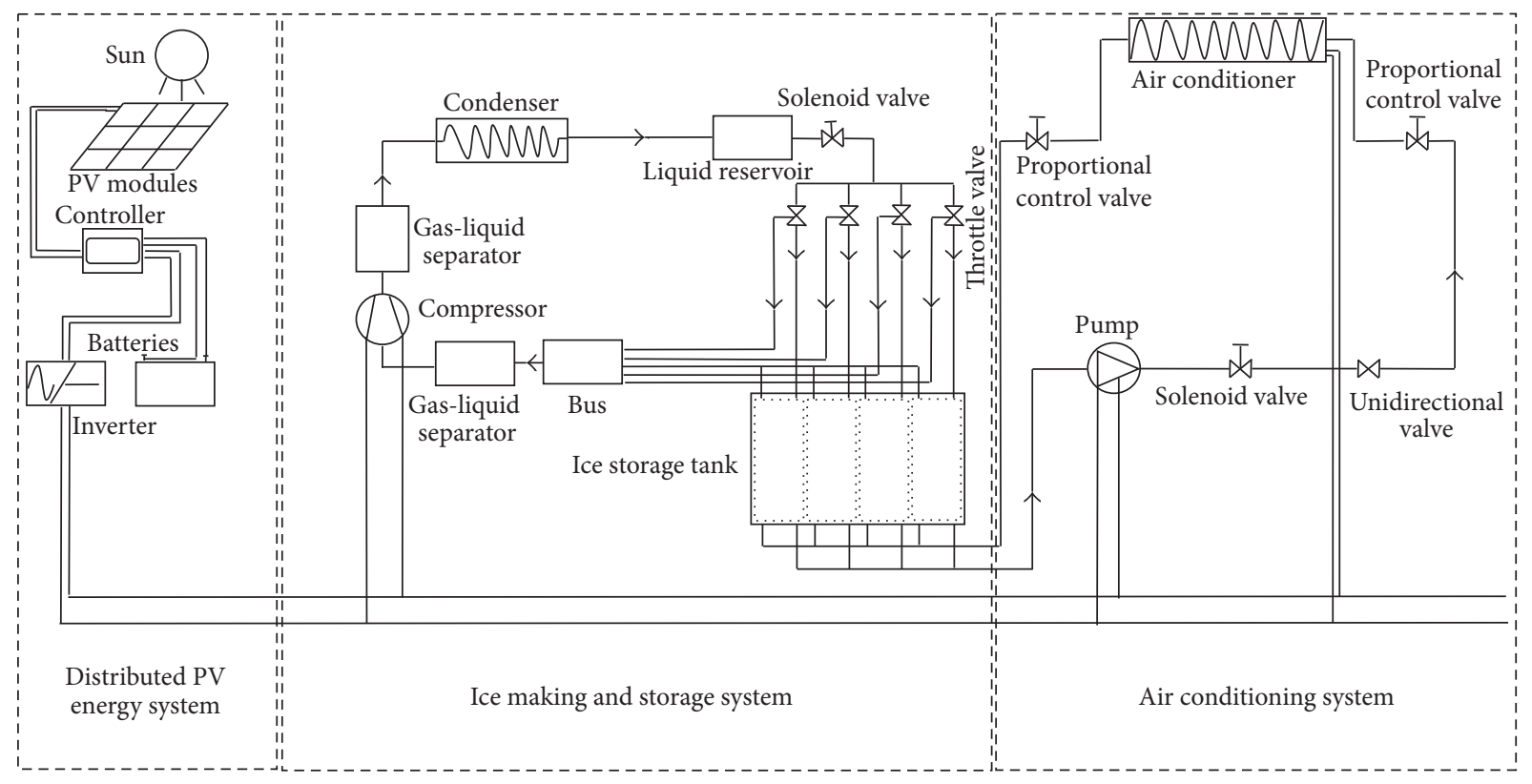

FIGURE 1: Work diagram of ISACS driven by DPES with batteries.

300 days for cooling demand; thereby ice storage has a good application prospect in those regions. So our research work has certain significance. In our system, a few batteries were also used in order to provide the stability for system operation. At first, a theoretical model has been established and experimental work has been done to analyze the energy coupling and transferring characteristics in light-electricitycold conversion process of ISACS driven by DPES. And then, the system optimization analysis was also investigated in order to achieve higher energy utilization efficiency and better financial rewards. In order to solve the problem of cold supplying process must lagging behind ice making process in traditional ice storage air conditioning system and improve the efficiency of traditional ice storage air conditioning system, system structure optimization analyses were investigated. So the immersed evaporator and cointegrated exchanger were suggested. Therefore, the present study can achieve the purpose of ISACS supplying cold efficiently with out-of-box functionality as the ordinary vapor compression air conditioning system. The research results can also provide some references for commercial application of ISACS driven by DPES without batteries in tropical regions without power grid.

\section{Materials and Methods}

\subsection{ISACS Driven by DPES}

2.1.1. Configuration of ISACS Driven by DPES. Ice storage air conditioning system (ISACS) driven by distributed photovoltaic energy system (DPES) was mainly configured by DPES, ice maker, storage system, and air conditioning system. The working diagram of ISACS driven by DPES is shown in Figure 1.
PV modules convert solar energy into electric energy which can be regulated by controller with maximum power point tracking to drive ice maker, ice storage system, and air conditioning system. In daytime, DPES receives solar energy and turns it into direct-current (DC) electric power which can be converted to alternating current (AC) electric power by inverter to drive AC compressor, water pump, ethylene glycol pump, and fan coil. To maintain the stability of electric energy supply, batteries were adopted and connected with controller to maintain the energy conversion and supply in the most optimized way. Ice maker and storage system were made up with AC compressor, condenser, expansion valve, disc evaporator, and ice storage tank. Circulating water can be frozen in a disc evaporator and the ice can be drooped into the ice storage tank when the hot refrigerant flowed into the evaporator which was controlled by the solenoid valve. Thereby, the ice maker worked as vapor compression refrigeration. In AC compressor, cryogenic R134a was compressed to high temperature and high pressure gas to be filtered in economizer and to release heat in condenser. Refrigerant was condensed to mild temperature and high pressure gas. When the gas inflows into throttle valve, it can be throttled to low temperature and low pressure liquid and then feeds into plate evaporator. And then, refrigerant flows into the other gasliquid separator to be sucked into the compressor. Thereby, the refrigeration cycle will be completed. Air conditioning system was mainly made up of coil heat exchanger which was fixed in ice storage tank, ethylene glycol pump, solenoid valve, proportional control valve, and fan coil. Ethylene glycol is an adopted cold exchanging medium.

According to the working principle diagram, $0.2 \mathrm{~kW}$ ISACS driven by DPES was established as shown in Figure 2. The main component parameters of ISACS driven by DPES are shown in Table 1. 
TABLE 1: Main component parameters of ISACS driven by DPES.

\begin{tabular}{|c|c|c|c|}
\hline & Component & Model & Parameters \\
\hline \multirow[b]{3}{*}{ DPES } & PV module & JN-245 & $\begin{array}{l}P_{m}: 245 \mathrm{~W}, V_{m}: 34.5 \mathrm{~V}, I_{m}: 7.10 \mathrm{~A}, V_{\mathrm{OC}}: 43.5 \mathrm{~V}, I_{\mathrm{SC}}: 8.18 \mathrm{~A} \text {, module: length } * \text { wide: } \\
1640 \mathrm{~mm} * 990 \mathrm{~mm} \text {, cells in series: length } * \text { wide } * \text { numbers: } 155 \mathrm{~mm} * 155 \mathrm{~mm} * 60\end{array}$ \\
\hline & Controller & PL60 & $12-48$ V 60 A charge, 30 A load \\
\hline & Inverter & Solar $48 \mathrm{~V}$ & $\begin{array}{l}P: 3 \mathrm{~kW} \text {, DC input voltage: } 48 \mathrm{~V} \text {, } \\
\text { output voltage: } 220 \mathrm{~V} \text {, output frequency: } 50 \mathrm{~Hz}\end{array}$ \\
\hline \multirow{7}{*}{ ISACS } & Batteries & SP12-65 & Battery capacity: $12 \mathrm{~V} 65 \mathrm{Ah}$, four batteries in series \\
\hline & Refrigerant & $\mathrm{R} 134 \mathrm{a}$ & Molecular formula: $\mathrm{CH}_{2} \mathrm{FCF}_{3}$, boiling point: $-26.1^{\circ} \mathrm{C}$, critical temperature: $101.1^{\circ} \mathrm{C}$ \\
\hline & Ice maker & IM50 & Ice production: $2.12 \mathrm{~kg} / \mathrm{h}, P: 380 \mathrm{~W}$ \\
\hline & Ice storage tank & / & Capacity: $20 \mathrm{~cm} * 20 \mathrm{~cm} * 20 \mathrm{~cm}$ \\
\hline & $\begin{array}{l}\text { Cold exchanging } \\
\text { medium }\end{array}$ & $\begin{array}{l}\text { Ethylene } \\
\text { glycol }\end{array}$ & Melting point: $-12.6^{\circ} \mathrm{C}$, viscosity: $25.66 \mathrm{mPa} \cdot \mathrm{s}$ \\
\hline & Pump & RS15-6 & Power: $46-93 \mathrm{~W}$, life: $6 \mathrm{~m}$, maximum flow rate: $3.4 \mathrm{~m}^{3} / \mathrm{h}$ \\
\hline & Fan coil & l & $\begin{array}{l}\text { Fan type: YS 56-2, power: } 180 \mathrm{~W} \text {, voltage: } 380 \mathrm{~V} \text {, current: } 0.53 \mathrm{~A} \text {, speed: } 2800 \mathrm{r} / \mathrm{min} \text {, } \\
\text { number of fins: } 95 \text {, size: } 23 \mathrm{~cm} * 8 \mathrm{~cm} * 20 \mathrm{~cm} \text {, coil numbers: } 26 \text {, coil inner diameter: } 6 \mathrm{~mm}\end{array}$ \\
\hline
\end{tabular}

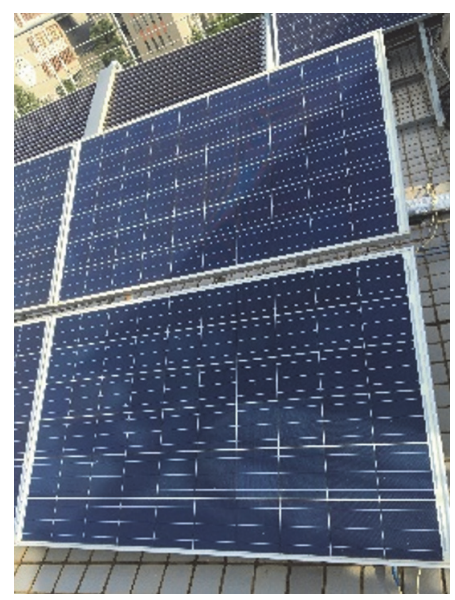

PV modules

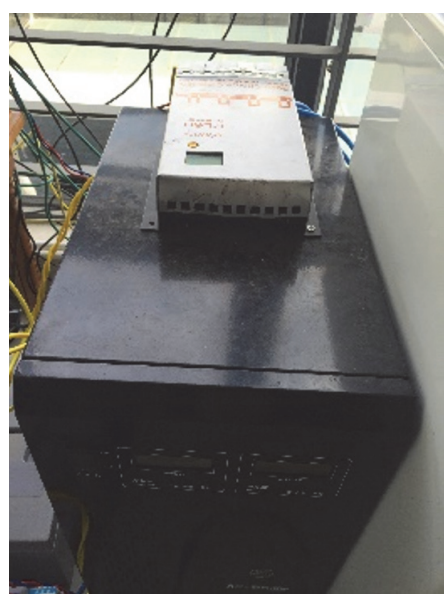

Controller and inverter

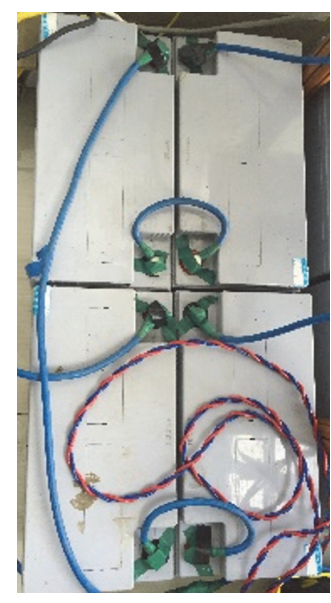

Batteries

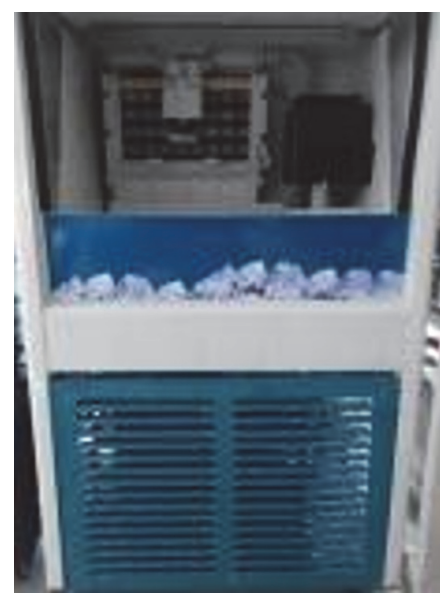

Ice maker

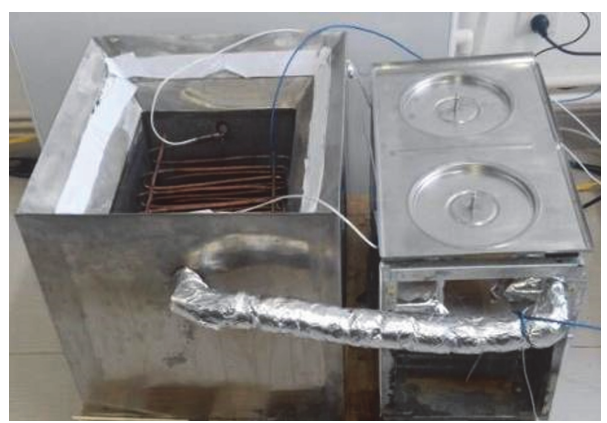

Ice storage tank

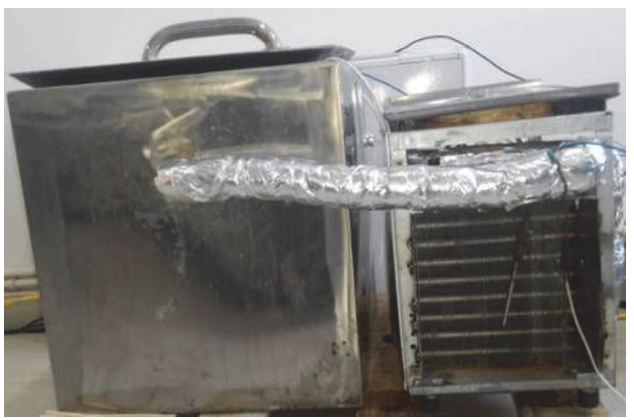

Fan coil

FIgURE 2: Pictures of $0.2 \mathrm{~kW}$ ISACS driven by DPES.

DPES were made up of two $245 W_{p}$ polycrystalline silicon PV in series and four batteries in series were used to store electric power. Refrigerant (R134a) temperatures and pressure were measured by T-type thermocouples and pressure transducers, respectively. Voltages and currents of PV modules were measured by a digital multimeter. The wind speed was measured by the wind speed transducer. Solar irradiation was measured by pyranometer. Compressor input power was measured by a wattmeter. Electromagnetic flow meter was used to measure refrigerant flow and cold exchanging medium flow. The parameters of all instruments are shown in Table 2. 
TABLE 2: Measuring instrument parameters and uncertainty.

\begin{tabular}{|c|c|c|c|c|c|c|c|}
\hline Instrument & Model & Range & Accuracy & $\begin{array}{l}\text { Application } \\
\text { scope }\end{array}$ & $\begin{array}{l}\text { Maximum } \\
\text { relative error }\end{array}$ & $\begin{array}{c}\text { Maximum } \\
\text { absolute error }\end{array}$ & $\begin{array}{l}\text { Uncertainty } \\
\text { (B class })\end{array}$ \\
\hline Pyranometer & $\begin{array}{c}\text { Kipp \& Zonen } \\
\text { CMP-6 }\end{array}$ & $0-2000\left(\mathrm{~W} / \mathrm{m}^{2}\right)$ & $\pm 5 \%$ & $0-1000\left(\mathrm{~W} / \mathrm{m}^{2}\right)$ & $\pm 10 \%$ & $\pm 100 \mathrm{~W} / \mathrm{m}^{2}$ & $57.7348 \mathrm{~W} / \mathrm{m}^{2}$ \\
\hline Thermocouples & $\mathrm{T}$ & -200 to $350\left({ }^{\circ} \mathrm{C}\right)$ & $\pm 0.4 \%$ & $0-150\left({ }^{\circ} \mathrm{C}\right)$ & $\pm 0.93 \%$ & $\pm 1.4^{\circ} \mathrm{C}$ & $0.8083^{\circ} \mathrm{C}$ \\
\hline $\begin{array}{l}\text { Wind speed } \\
\text { transducer }\end{array}$ & EC-9S & $0-70(\mathrm{~m} / \mathrm{s})$ & $\pm 0.4 \%$ & $0-10(\mathrm{~m} / \mathrm{s})$ & $\pm 2.8 \%$ & $\pm 0.28 \mathrm{~m} / \mathrm{s}$ & $0.1617 \mathrm{~m} / \mathrm{s}$ \\
\hline $\begin{array}{l}\text { Electromagnetic flow } \\
\text { meter }\end{array}$ & $\begin{array}{l}\text { KROHNE } \\
\text { OPTIFLUX } \\
5000\end{array}$ & DN 5; 0-12(m/s) & $\pm 0.15 \%$ & $0-5(\mathrm{~m} / \mathrm{s})$ & $\pm 0.36 \%$ & $\pm 0.018 \mathrm{~m} / \mathrm{s}$ & $0.0104 \mathrm{~m} / \mathrm{s}$ \\
\hline Pressure transducer & $\begin{array}{c}\text { YOKOGAWA } \\
\text { EJA430E }\end{array}$ & $0.14-16(\mathrm{MPa})$ & $\pm 0.055 \%$ & $0-2(\mathrm{MPa})$ & $\pm 0.44 \%$ & $\pm 0.0088 \mathrm{MPa}$ & $0.0051 \mathrm{MPa}$ \\
\hline Electronic balance & AHW-3 & $0-3 \mathrm{~kg}$ & $\pm 0.05 \mathrm{~g}$ & $0-3 \mathrm{~kg}$ & $\pm 0.05 \%$ & $\pm 0.0015 \mathrm{~kg}$ & $0.0009 \mathrm{MPa}$ \\
\hline Wattmeter & $\begin{array}{l}\text { DELIXI } \\
\text { DDS607 }\end{array}$ & $0-10000 \mathrm{~kW} \cdot \mathrm{h}$ & $\pm 0.01 \mathrm{~kW} \cdot \mathrm{h}$ & 0-100 kW·h & $\pm 1 \%$ & $\pm 1 \mathrm{~kW} \cdot \mathrm{h}$ & $0.5774 \mathrm{~kW} \cdot \mathrm{h}$ \\
\hline \multirow[t]{2}{*}{ Digital multimeter } & \multirow{2}{*}{ FLUKE F-179 } & Voltage: $0-1000 \mathrm{~V}$ & $\pm 0.9 \%$ & $0-380 \mathrm{~V}$ & $\pm 2.37 \%$ & $\pm 9.006 \mathrm{~V}$ & $5.1996 \mathrm{~V}$ \\
\hline & & Current: 0-10 A & $\pm 1 \%$ & $0-10 \mathrm{~A}$ & $\pm 1 \%$ & $\pm 0.1 \mathrm{~A}$ & $0.0577 \mathrm{~A}$ \\
\hline
\end{tabular}

2.2. Theoretical Models on Energy Conversion and Transfer Characteristics of ISACS Driven by DPES. Theoretical model was established to analyze the energy conversion and transfer characteristics of ISACS driven by DPES as follows.

2.2.1. Energy and Exergy Models of PV Modules. Energy balance equation of $\mathrm{PV}$ modules is expressed as

$$
\left(m_{p} C_{p_{\text {module }}}\right) T_{p}=Q_{\mathrm{PV}, \text { in }}-Q_{\mathrm{PV}, \text { loss }}-Q_{\mathrm{PV}, \text { elect }} .
$$

Solar energy absorbed by PV modules can be estimated as

$$
\mathrm{Q}_{\mathrm{PV}, \text { in }}=\alpha \tau G S_{p} .
$$

Electric power is expressed by

$$
Q_{\mathrm{PV}, \text { elect }}=V_{\text {out }} I_{\text {out }} \cdot
$$

Exergy and exergy losses of PV modules are given in [26]:

$$
\begin{aligned}
& \Delta E_{\mathrm{PV}}=Q_{\mathrm{PV}, \text { loss }}\left(1-\frac{T_{a}}{T_{P}}\right)+\left[I_{\mathrm{sc}} V_{\mathrm{oc}}-I_{m} V_{m}\right], \\
& E_{\mathrm{PV}, \text { in }}=G S_{p}\left[1-\frac{4}{3} \frac{T_{a}}{T_{\text {sun }}}+\frac{1}{3}\left(\frac{T_{a}}{T_{\text {sun }}}\right)^{4}\right], \\
& E_{\mathrm{PV}, \text { in }}=E_{\mathrm{PV}, \text { out }}+\Delta E_{\mathrm{PV}} .
\end{aligned}
$$

2.2.2. Energy and Exergy Models of Controller. Energy balance equation of controller can be estimated as follows:

$$
Q_{\mathrm{PV}, \text { elect }}=Q_{C, \text { out }}+Q_{C, \text { loss }} .
$$

$Q_{C, \text { loss }}$ is the consumed energy by controller per unit time (W); usually $Q_{C \text {,loss }}$ is $4 \%$ of $Q_{\mathrm{PV} \text {,elect }}$.
Exergy and exergy losses of controller are expressed as in [27]:

$$
\begin{aligned}
& \Delta E_{C}=Q_{C, \text { loss }}\left(1-\frac{T_{a}}{T_{C}}\right), \\
& E_{C, \text { in }}=E_{C, \text { out }}+\Delta E_{C} .
\end{aligned}
$$

2.2.3. Energy and Exergy Models of Batteries. Energy balance equations of batteries are given by [28]

$$
Q_{B, \text { in }}=\xi Q_{B, \text { out }}+Q_{B, \text { loss }}-\xi Q_{B, \text { storage }}
$$

$\xi$ is a symbolic coefficient. When batteries supply power to load, $\xi$ is assigned 1 . On the contrary, $\xi$ is assigned -1 when batteries are charged:

$$
Q_{B, \text { loss }}=I_{B}^{2}\left[r_{1}+r_{2}(\mathrm{SOC})+\frac{1}{r_{3}-r_{4}(\mathrm{SOC})}\right] .
$$

Here,

$$
\mathrm{SOC}=\mathrm{SOC}_{0}+\frac{\int_{0}^{t} I_{B} d t}{\mathrm{BC}} .
$$

VF is the full charge rest voltage $(\mathrm{V}), \mathrm{SOC}_{0}$ is the initial SOC value (1), and BC is batteries capacity (Ah).

Exergy balance and exergy loss equations of batteries are written as [27]

$$
\begin{aligned}
& \Delta E_{B}=Q_{B, \text { loss }}\left(1-\frac{T_{a}}{T_{B}}\right), \\
& E_{B, \text { in }}=E_{B, \text { out }}+\Delta E_{B} .
\end{aligned}
$$

2.2.4. Energy and Exergy Models of Inverter. Energy balance empirical equations of inverter are given in [28]:

$$
\begin{aligned}
Q_{I, \text { loss }} & =\frac{C_{P}}{C_{R}}+\frac{C_{R}-1}{C_{R}}\left(Q_{C, \text { out }}+Q_{B, \text { out }}\right), \\
Q_{C, \text { out }}+Q_{B, \text { out }} & =Q_{I, \text { out }}+Q_{I, \text { loss }} .
\end{aligned}
$$




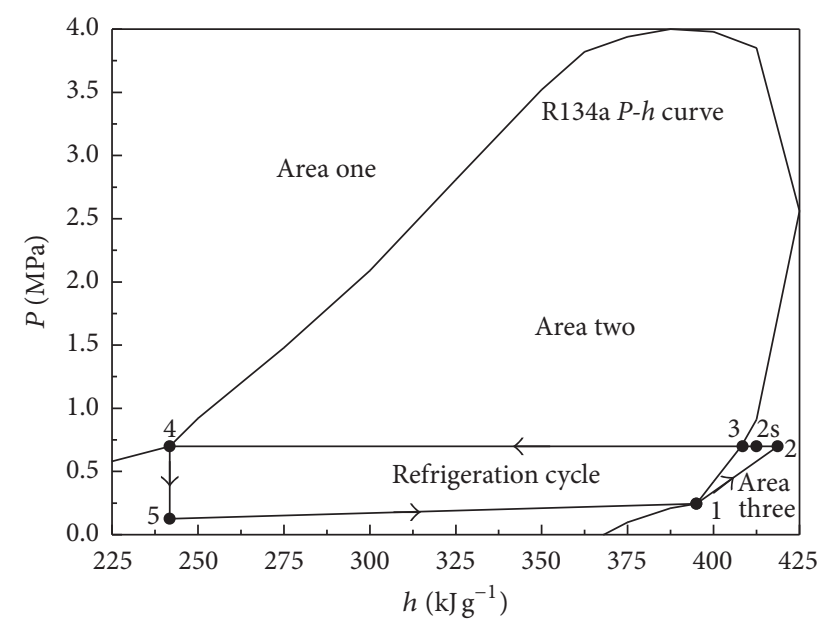

FIgURE 3: R134a thermodynamic curve.

Exergy balance and exergy loss equations of inverter are expressed in [28]:

$$
\begin{aligned}
\Delta E_{I} & =Q_{I, \text { loss }}\left(1-\frac{T_{a}}{T_{I}}\right), \\
E_{C, \text { out }}+E_{B, \text { out }} & =E_{I, \text { out }}+\Delta E_{I} .
\end{aligned}
$$

2.2.5. Energy and Exergy Models of ISACS. ISACS are driven by stable electric energy outputted by DPES. The thermodynamic cycle refrigeration process of ice maker, refrigerant, R134a thermodynamic properties, and $P$ - $h$ changing curve of refrigerant R134a in refrigeration cycle are shown in Figure 3. It can be clearly seen in Figure 3 that area 1 is the saturated liquid, area 2 is the gas-liquid coexistence, and area 3 is the saturated vapor. Consequently, the refrigeration cycle was 1-2-2s-3-4-5-1 across the saturated vapor region and gasliquid coexistence region. The process from 1-2 is showing an actual compressor working process, when the dry steam in state 1 is compressed to saturated vapor in state 2 , which will be isentropic compressed to $2 \mathrm{~s}$ under ideal condition. However, the process $2-2 s-3-4$ is the refrigerant condensing and releasing heat process in condenser. The process $2-2 \mathrm{~s}$ is the natural cooling process and 2s-3-4 is the isobaric cooling process. The cryogen will be high pressure dry steam in state 3 and high pressure saturated liquid in state 4 . The process 4-5 is the decompression cooling by throttle valve. Therefore, by flowing through throttle valve, the refrigerant temperature and pressure will be low and then it can flow into evaporator to absorb heat and refrigerate, which is the process 5-1.

Energy and exergy analyses are shown as follows.

(a) The compressor energy balance equation is given by

$$
\dot{m}_{\mathrm{rf}} h_{1}+W=\dot{m}_{\mathrm{rf}} h_{2}+Q_{\mathrm{CP}, \text { loss }} .
$$

Compressor exergy model is given as

$$
\begin{aligned}
& E_{\mathrm{CP}, \text { in }}=\Delta E_{\mathrm{CP}}+E_{\mathrm{CP}, \text { out }}, \\
& \Delta E_{\mathrm{CP}}=\dot{m}_{\mathrm{rf}}\left[\left(h_{2}-h_{1}\right)-T_{a}\left(s_{2}-s_{1}\right)\right] .
\end{aligned}
$$

(b) The condenser energy balance equation is shown as

$$
\begin{aligned}
\dot{m}_{\mathrm{rf}} h_{3} & =\dot{m}_{\mathrm{rf}} h_{4}+Q_{E}+Q_{\mathrm{CO}, \text { loss }}, \\
Q_{E} & =\dot{m}_{\text {air,icemk }} C_{p \text {,air }}\left(T_{\text {air,out }}-T_{\text {air,in }}\right) .
\end{aligned}
$$

Condenser exergy model is expressed as

$$
\begin{aligned}
\Delta E_{\mathrm{CO}}= & \dot{m}_{\mathrm{rf}}\left[\left(h_{3}-h_{4}\right)-T_{a}\left(s_{3}-s_{4}\right)\right] \\
& -Q_{E}\left(1-\frac{T_{\text {air,in }}}{T_{\text {air,out }}}\right) \\
E_{\mathrm{CO}, \text { in }}= & E_{\mathrm{CO}, \text { out }}+\Delta E_{\mathrm{CO}} .
\end{aligned}
$$

(c) It is isenthalpic throttling process to refrigerant in throttle valve, so

$$
Q_{\mathrm{CO}, \text { out }}=Q_{\mathrm{TH}, \text { out }} \cdot
$$

Throttle valve exergy model is given by

$$
\begin{aligned}
& \Delta E_{\mathrm{TH}}=\dot{m}_{\mathrm{rf}} T_{a}\left(s_{5}-s_{4}\right), \\
& E_{\mathrm{TH}, \text { in }}=E_{\mathrm{TH}, \text { out }}+\Delta E_{\mathrm{TH}} .
\end{aligned}
$$

(d) Evaporator energy balance equation is shown as

$$
Q_{\mathrm{EV}, \text { in }}=Q_{\mathrm{EV}, \text { out }}+Q_{\mathrm{AB}}+Q_{\mathrm{EV}, \text { loss }} .
$$

$Q_{A B}$ is evaporator absorption heat from water (W).

Evaporator exergy model is given by

$$
\begin{aligned}
\Delta E_{\mathrm{EV}} & =\dot{m}_{\mathrm{rf}}\left[\left(h_{1}-h_{5}\right)-T_{a}\left(s_{1}-s_{5}\right)\right], \\
E_{\mathrm{AB}, \text { in }} & =Q_{\mathrm{AB}}\left(1-\frac{T_{\mathrm{EV}}}{T_{a}}\right), \\
E_{\mathrm{EV}, \text { in }}+E_{\mathrm{AB}, \text { in }} & =E_{\mathrm{EV}, \text { out }}+\Delta E_{\mathrm{EV}} .
\end{aligned}
$$

Energy balance equations in cold exchanging and supplying process are written as

$$
\begin{aligned}
& Q_{\text {ice,storage }}=Q_{\text {air,fancoil }}+\Delta Q_{\text {ice,loss }}, \\
& Q_{\text {air,fancoil }} \\
& \quad=\int_{0}^{t} \dot{m}_{\text {air,fancoil }} C_{p \text {,air }}\left(T_{\text {air,fancoil-in }}-T_{\text {air,fancoil-out }}\right) d t, \\
& Q_{\text {ice,storage }}=m_{\text {ice }} h_{\text {ice }} .
\end{aligned}
$$

And exergy calculation equation is shown:

$$
E_{\text {ice,in }}=Q_{\text {air }}\left(1-\frac{T_{\text {air,fancoil-out }}}{T_{\text {air,fancoil-in }}}\right)+\Delta E_{\text {ice }} \text {. }
$$

The energy conversion and transmission efficiency $\eta$ and exergy efficiency $\psi$ of each component of the system can be calculated by the following formulas:

$$
\begin{gathered}
\eta=\frac{Q_{\text {out }}}{Q_{\text {in }}}, \\
\psi=\frac{E_{\text {out }}}{E_{\text {in }}} .
\end{gathered}
$$




\section{Results and Discussion}

3.1. Calculation Results and Analysis. The related parameters are shown in Table 3.

08:00-17:00 is the working time from Monday to Friday. During working time, the cold demand in the house is very low, so the refrigerator can be driven by PV modules and then the cold can be stored in the ice storage tank. After work, the cold demands of the house increased and the cold stored in the daytime can be charged to service family. So the ISACS driven by DPES has great application prospects in domestic cooling field.

The ISACS driven by DPES operated from 08:00 to 23:00. In daytime, solar energy was converted into electrical energy by PV modules. Before 11:00 AM, the irradiation was too low and the electricity generated by PV modules cannot drive ice maker. At the same time, batteries discharged to make up for the lack of electricity produced by PV modules and the ice maker could operate stably and reliably driven by photovoltaic battery hybrid energy supply system. And then, the irradiation gradually increased and the electricity increased along with irradiance. In hybrid energy supply system, the system output power was equal to the power rating of ice maker and was always the same but PV modules output power increased and batteries output power decreased accordingly. About $11 \mathrm{AM}$, the output power of PV modules was enough to drive ice maker so the output power of batteries is zero. After $11 \mathrm{AM}$, with the continuous increase of irradiance, not only was the electricity of PV modules used to drive ice maker but also the surplus electricity was stored in batteries. So the batteries were in charge. After noon, the irradiation from sun decreased step by step and so the electricity generated by PV modules reduced gradually. About 14:00, the electricity reducing step by step was only enough to drive ice maker. The charge state of batteries was end. Then, ice maker was driven by PV modules and batteries once again until the ice was enough at 16:00. All of the ice was stored in ice storage tank and the cold can be exchanged by the coil with refrigerating medium ethylene glycol flowing in it at 19:00. At the other end of the coil the cold of refrigerating medium can be blown into the air in the house by fan. So the temperature of house dropped step by step until it tended to balance. About 23:00, the cold of ice in the tank was released completely. And then, the fan and glycol pump would be shut down and the cold supply process was over. Through all of the process, energy is transformed from light to electricity by PV modules and it is stored with ice through phase change latent heat of water. In conversion and transmission process, the energy and exergy of system changed with the change of external environmental conditions. In order to describe system performance clearly and intuitively, the overall performance of the system was evaluated. So the energy efficiency and exergy efficiency of each component of the system in energy conversion and transmission process were calculated and the results are shown in Table 4.

Figure 4 showed the change curves of energy efficiency and exergy efficiency of ice making and cold-storing process from 08:00 to 16:00 with ice maker driven by DPES. Figure 5
TABLE 3: Related parameters of ISACS driven by DPES.

\begin{tabular}{|c|c|}
\hline Parameters & Value \\
\hline \multicolumn{2}{|l|}{ Outside } \\
\hline$T_{s} / \mathrm{K}$ & 5778 \\
\hline$T_{a} / \mathrm{K}$ & $286.36-298$ \\
\hline$v /\left(\mathrm{m} \cdot \mathrm{s}^{-1}\right)$ & $0.87-1.55$ \\
\hline$q / \mathrm{MJ} \cdot \mathrm{m}^{-2}(08: 00-16: 00)$ & 22.17 \\
\hline \multicolumn{2}{|l|}{ PV modules } \\
\hline $\mathrm{Q} / \mathrm{kW} \cdot \mathrm{h}(08: 00-16: 00)$ & 2.76 \\
\hline$S_{p} / \mathrm{m}^{2}$ & 2.88 \\
\hline$S_{c} / \mathrm{m}^{2}$ & 3.24 \\
\hline$V_{\mathrm{OC}} / \mathrm{V}$ & 89.35 \\
\hline$I_{\mathrm{SC}} / \mathrm{A}$ & 8.18 \\
\hline$V_{\text {out }} / \mathrm{V}$ & $50.90-54.20$ \\
\hline$I_{\text {out }} / \mathrm{A}$ & $0.50-8.50$ \\
\hline$V_{m} / \mathrm{V}$ & 34.50 \\
\hline$I_{m} / \mathrm{A}$ & 7.10 \\
\hline$\eta_{0} / \%$ & 17.50 \\
\hline$\alpha$ & 0.92 \\
\hline$\tau$ & 0.90 \\
\hline$m /\left(\mathrm{kg} \cdot \mathrm{m}^{-2}\right)$ & 23 \\
\hline$C_{\text {pmodule }} /\left(\mathrm{J} \cdot \mathrm{kg}^{-1} \cdot \mathrm{K}^{-1}\right)$ & 1179.06 \\
\hline$T_{P} / \mathrm{K}$ & $287.04-325.15$ \\
\hline \multicolumn{2}{|l|}{ Controller } \\
\hline$T_{C} / \mathrm{K}$ & 303.15 \\
\hline \multicolumn{2}{|l|}{ Storage batteries } \\
\hline C & $48 \mathrm{~V} 65 \mathrm{Ah}$ \\
\hline$T_{B} / \mathrm{K}$ & 313.15 \\
\hline \multicolumn{2}{|l|}{ Charging } \\
\hline$B$ & 0.80 \\
\hline VF & 56.53 \\
\hline$V_{B} / \mathrm{V}$ & $47.60-52.53$ \\
\hline$I_{B} / \mathrm{A}$ & 8.00 \\
\hline$r_{1}$ & 0.060 \\
\hline$r_{2}$ & 0.041 \\
\hline$r_{3}$ & 95.234 \\
\hline$r_{4}$ & 51.856 \\
\hline \multicolumn{2}{|l|}{ Discharging } \\
\hline$B$ & 0.70 \\
\hline VF & 54.88 \\
\hline$V_{B} / \mathrm{V}$ & $54.88-44.60$ \\
\hline$I_{B} / \mathrm{A}$ & $5.50-7.40$ \\
\hline$r_{1}$ & 0.052 \\
\hline$r_{2}$ & -0.012 \\
\hline$r_{3}$ & 4.113 \\
\hline$r_{4}$ & -100.653 \\
\hline \multicolumn{2}{|l|}{ Inverter } \\
\hline$T_{I} / \mathrm{K}$ & 318.15 \\
\hline$C_{p}$ & 10.045 \\
\hline$C_{R}$ & 1.1885 \\
\hline
\end{tabular}


TABLe 3: Continued.

\begin{tabular}{|c|c|}
\hline Parameters & Value \\
\hline \multicolumn{2}{|l|}{ Compressor } \\
\hline$\dot{m} /\left(\mathrm{kg} \cdot \mathrm{s}^{-1}\right)$ & 0.0127 \\
\hline$W_{p} / \mathrm{W}$ & $328.31-340.25$ \\
\hline$T_{\text {in }} / \mathrm{K}$ & 268.15 \\
\hline$T_{\text {out }} / \mathrm{K}$ & 313.15 \\
\hline$P_{\text {in }} / \mathrm{kPa}$ & 243.71 \\
\hline$P_{\text {out }} / \mathrm{kPa}$ & 770.21 \\
\hline$h_{\text {in }} /\left(\mathrm{kJ} \cdot \mathrm{kg}^{-1}\right)$ & 395.01 \\
\hline$h_{\text {out }} /\left(\mathrm{kJ} \cdot \mathrm{kg}^{-1}\right)$ & 425.00 \\
\hline$s_{\text {in }} /\left(\mathrm{kJ} \cdot \mathrm{kg}^{-1} \cdot \mathrm{K}^{-1}\right)$ & 1.7276 \\
\hline$s_{\text {out }} /\left(\mathrm{kJ} \cdot \mathrm{kg}^{-1} \cdot \mathrm{K}^{-1}\right)$ & 1.7500 \\
\hline \multicolumn{2}{|l|}{ Condenser } \\
\hline$T_{\text {in }} / \mathrm{K}$ & 313.15 \\
\hline$T_{\text {out }} / \mathrm{K}$ & 303.15 \\
\hline$P_{\text {in }} / \mathrm{kPa}$ & 700.00 \\
\hline$P_{\text {out }} / \mathrm{kPa}$ & 700.00 \\
\hline$h_{\mathrm{in}} /\left(\mathrm{kJ} \cdot \mathrm{kg}^{-1}\right)$ & 425.00 \\
\hline$h_{\text {out }} /\left(\mathrm{kJ} \cdot \mathrm{kg}^{-1}\right)$ & 241.80 \\
\hline$s_{\text {in }} /\left(\mathrm{kJ} \cdot \mathrm{kg}^{-1} \cdot \mathrm{K}^{-1}\right)$ & 1.7500 \\
\hline$s_{\text {out }} /\left(\mathrm{kJ} \cdot \mathrm{kg}^{-1} \cdot \mathrm{K}^{-1}\right)$ & 1.1437 \\
\hline$\dot{m}_{\text {air,icemk }} /\left(\mathrm{kg} \cdot \mathrm{s}^{-1}\right)$ & 0.21 \\
\hline$C_{p, \text { air }} /\left(\mathrm{J} \cdot \mathrm{kg}^{-1} \cdot \mathrm{K}^{-1}\right)$ & 1000 \\
\hline$T_{\text {air,in }} / \mathrm{K}$ & $286.36-296$ \\
\hline$T_{\text {air,out }} / \mathrm{K}$ & $291.36-301$ \\
\hline \multicolumn{2}{|l|}{ Throttle valve } \\
\hline$T_{\text {in }} / \mathrm{K}$ & 303.15 \\
\hline$T_{\text {out }} / \mathrm{K}$ & 263.15 \\
\hline$P_{\text {in }} / \mathrm{kPa}$ & 700.00 \\
\hline$P_{\text {out }} / \mathrm{kPa}$ & 200.00 \\
\hline$h_{\mathrm{in}} /\left(\mathrm{kJ} \cdot \mathrm{kg}^{-1}\right)$ & 241.80 \\
\hline$h_{\text {out }} /\left(\mathrm{kJ} \cdot \mathrm{kg}^{-1}\right)$ & 241.80 \\
\hline$s_{\text {in }} /\left(\mathrm{kJ} \cdot \mathrm{kg}^{-1} \cdot \mathrm{K}^{-1}\right)$ & 1.1437 \\
\hline$s_{\text {out }} /\left(\mathrm{kJ} \cdot \mathrm{kg}^{-1} \cdot \mathrm{K}^{-1}\right)$ & 1.1500 \\
\hline \multicolumn{2}{|l|}{ Evaporator } \\
\hline$T_{\text {in }} / \mathrm{K}$ & 263.15 \\
\hline$T_{\text {out }} / \mathrm{K}$ & 268.15 \\
\hline$P_{\text {in }} / \mathrm{kPa}$ & 200.00 \\
\hline$P_{\text {out }} / \mathrm{kPa}$ & 243.71 \\
\hline$h_{\mathrm{in}} /\left(\mathrm{kJ} \cdot \mathrm{kg}^{-1}\right)$ & 241.80 \\
\hline$h_{\text {out }} /\left(\mathrm{kJ} \cdot \mathrm{kg}^{-1}\right)$ & 395.01 \\
\hline$s_{\text {in }} /\left(\mathrm{kJ} \cdot \mathrm{kg}^{-1} \cdot \mathrm{K}^{-1}\right)$ & 1.1500 \\
\hline$s_{\text {out }} /\left(\mathrm{kJ} \cdot \mathrm{kg}^{-1} \cdot \mathrm{K}^{-1}\right)$ & 1.7276 \\
\hline \multicolumn{2}{|c|}{ Cold exchanging and supplying } \\
\hline$T_{\text {ice-tank }} / \mathrm{K}$ & $272.20-278.15$ \\
\hline$T_{\text {glycol }} / \mathrm{K}$ & $276.62-285.15$ \\
\hline$T_{\text {air,fancoil-in }} / \mathrm{K}$ & $293.45-289.95$ \\
\hline$T_{\text {air,fancoil-out }} / \mathrm{K}$ & $293.45-287.65$ \\
\hline$m_{\mathrm{ICE}} / \mathrm{kg}$ & 16.98 \\
\hline$h_{\mathrm{ICE}} /\left(\mathrm{kJ} \cdot \mathrm{kg}^{-1}\right)$ & 335 \\
\hline$\dot{m}_{\text {air,fancoil }} /\left(\mathrm{kg} \cdot \mathrm{s}^{-1}\right)$ & 0.12 \\
\hline$t_{\text {cold }} / \mathrm{s}$ & 14400 \\
\hline
\end{tabular}

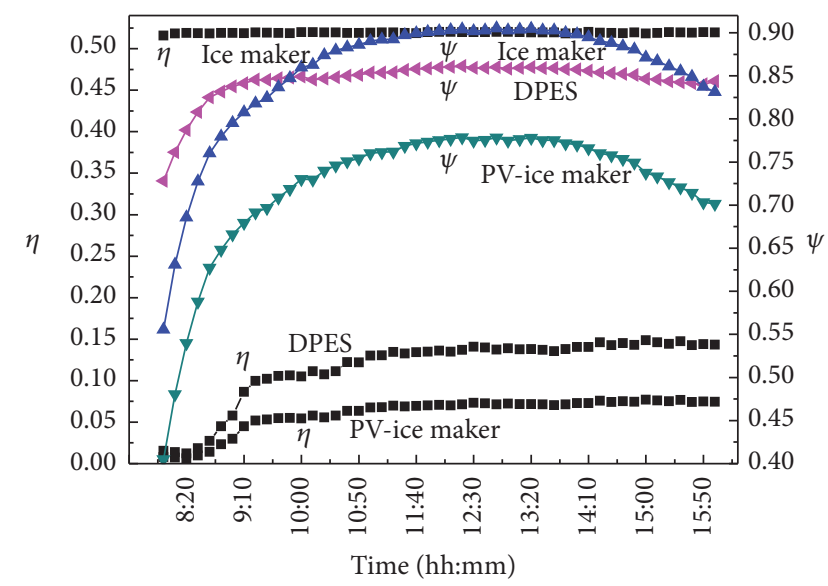

FIGURE 4: Energy efficiency and exergy efficiency of ice maker driven by DPES.

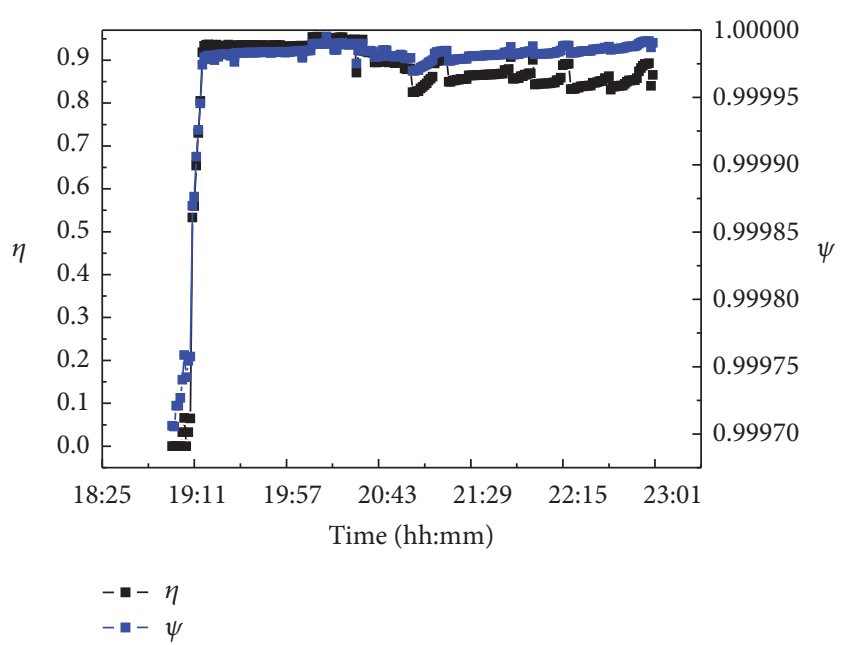

FIGURE 5: Energy efficiency and exergy efficiency of fan coil driven by DPES.

showed the change curves of system energy efficiency and exergy efficiency of fan coil driven by DPES from 19:00 to 23:00.

In daytime, ice maker system was driven by DPES batteries and the system energy efficiency and exergy efficiency were $5.44 \%$ and $67.30 \%$, respectively. It was found that the total energy efficiency and total exergy efficiency of DPES were $12.44 \%$ and $84.95 \%$, respectively, and the total energy efficiency and total exergy efficiency of ice maker system were $51.20 \%$ and $79.77 \%$, respectively. After $16: 00$, the total ice production was $16.98 \mathrm{~kg}$. All of the ice was stored in the tank and air conditioner was open at 19:00 and sustained for about 4 hours with $85.42 \%$ total energy efficiency and $99.31 \%$ exergy efficiency.

It was observed that in ice maker thermodynamic cycle refrigeration efficiency was only $17.38 \%$ and the wastage in cooling process was $45093.78 \mathrm{~W}$. In the ice making process, the water can be pumped by a recycle pump and flowed through evaporator to absorb heat. A part of water can be 
TABLE 4: Calculated results of total energy and total exergy of each component of the system in energy conversion and transmission process.

\begin{tabular}{|c|c|c|c|c|c|c|c|}
\hline & Accepted energy/W & Accepted exergy/W & \multicolumn{2}{|c|}{ Useful power/W } & Useful exergy/W & $\eta / \%$ & $\psi / \%$ \\
\hline PV module & 100007.5 & 112560.5 & \multicolumn{2}{|c|}{15889.79} & 95910.39 & 15.89 & 85.21 \\
\hline Controller & 15889.79 & 95910.39 & \multicolumn{2}{|c|}{15254.2} & 95894.55 & 96.00 & 99.98 \\
\hline Batteries & 15254.2 & 95894.55 & \multicolumn{2}{|c|}{15162.49} & 95887.94 & 99.40 & 99.99 \\
\hline Inverter & 19772.17 & 95887.94 & \multicolumn{2}{|c|}{16222.1} & 95621.2 & 82.05 & 99.72 \\
\hline \multicolumn{6}{|c|}{ Distributed photovoltaic energy system } & 12.44 & 84.95 \\
\hline Compressor & 156936.5 & 95621.2 & \multicolumn{2}{|c|}{151397.8} & 87286.14 & 96.47 & 91.28 \\
\hline Condenser & 151397.8 & 87286.14 & $\begin{array}{c}\text { Air } \\
\text { Refrigeration }\end{array}$ & $\begin{array}{c}51450 \\
86136.41\end{array}$ & 86445.17 & 90.88 & 99.04 \\
\hline Throttle valve & 86136.41 & 86445.17 & \multicolumn{2}{|c|}{86136.41} & 85784.72 & 100 & 99.24 \\
\hline Evaporator & 86136.41 & 85784.72 & $\begin{array}{c}\text { Output } \\
\text { Absorbing }\end{array}$ & $\begin{array}{c}140714.4 \\
54578\end{array}$ & 79810.74 & 336 & 93.04 \\
\hline \multirow[t]{2}{*}{ Ice } & 54578 & 79810.74 & \multicolumn{2}{|c|}{9484.22} & 76271.06 & 17.38 & 95.57 \\
\hline & & Ice maker system & & & & 51.20 & 79.77 \\
\hline \multirow[t]{2}{*}{ Air conditioning system } & 94842.22 & 76271.06 & \multirow{2}{*}{\multicolumn{2}{|c|}{81009.64}} & 75747.45 & 85.42 & 99.31 \\
\hline & & ISACS driven by DPES & & & & 5.44 & 67.30 \\
\hline
\end{tabular}

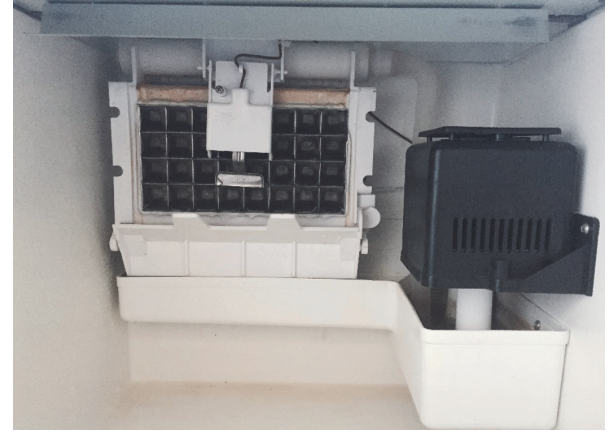

FIGURE 6: Ice slide maker (internal picture).

frozen on the evaporator and the rest of water flowed back to the water storage. Thereby, in the water circulating process, the circulating water consumed much of the energy, as shown in Figure 6.

In ice maker, compressor was the maximum exergy loss component with $8.78 \%$ exergy loss efficiency and it is clear that the evaporator is the most important component of ice maker; the total exergy of evaporator was $79810.74 \mathrm{~W}$ and the exergy efficiency was $93.04 \%$. At the same time, the exergy flow from water to the evaporator was $76271.06 \mathrm{~W}$ with $95.57 \%$ exergy efficiency in ice making process.

\subsection{Experimental Results and Analysis}

3.2.1. DPES. The output performance of PV modules was greatly affected by the external environment such as solar irradiance, wind speed, ambient temperature, and PV modules temperature. Therefore, the external environment should be tested through the experiment to calculate and analyze PV output performance. ISACS driven by DPES tested on October 22 in Kunming. Results showed that the irradiation quantity $q$ was $22.17 \mathrm{MJ} / \mathrm{m}^{2}$ from 8:00 to $16: 00$ and the total

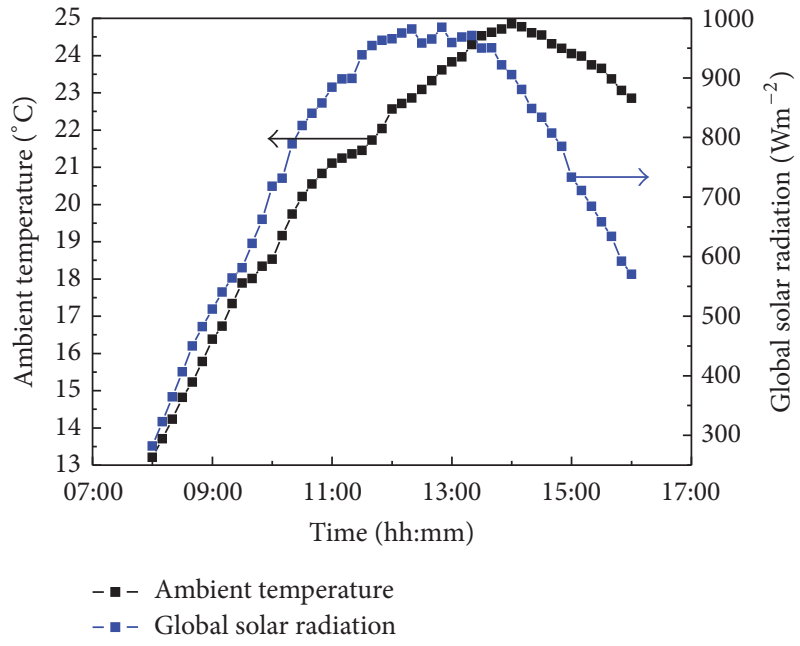

FIGURE 7: Variations of global solar radiation and ambient temperature on 22nd Nov., 2015, in Kunming.

amount of ice was $16.98 \mathrm{~kg}$ when the fan coil operated for nearly 4 hours. Meanwhile, PV modules output performances were tested and analyzed. Firstly, global solar radiation and ambient temperature were tested, as shown in Figure 7. PV modules temperature is a decisive component of output performance, which can be affected by wind speed changing at any time. Thus, wind speed and PV modules temperature can only be obtained by experimental measurement, as shown in Figure 8.

The voltage and current variations of PV modules were also tested on October 22 in Kunming. The variation curves are shown in Figure 9. Batteries were adopted in testing process to ensure power output stability and store excess power generated by PV modules. The voltage and current of batteries were also measured and variation curves are also shown in Figure 10. 


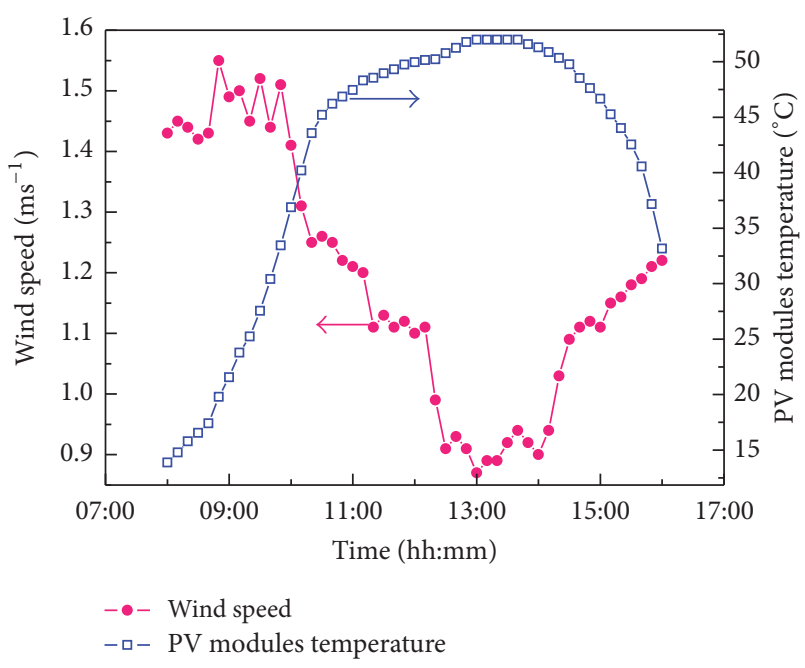

FIGURE 8: Variations of wind speed and PV modules temperature on 22nd Nov., 2015, in Kunming.

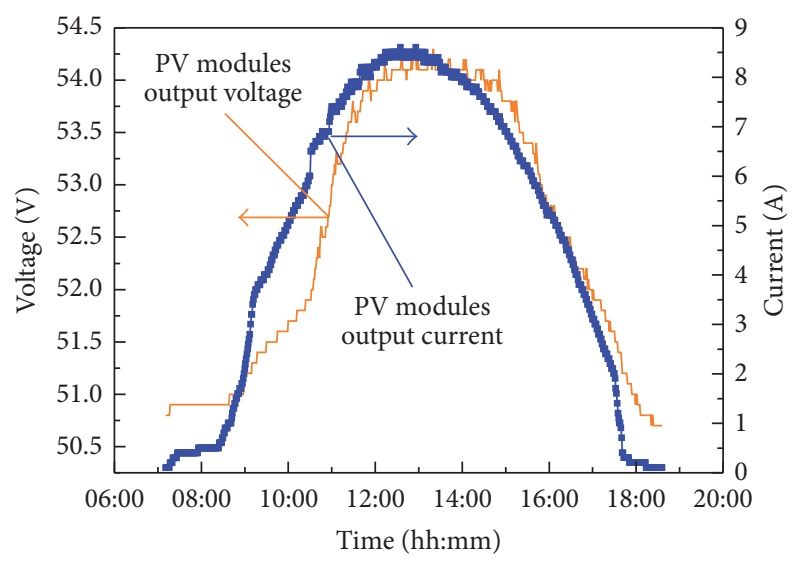

FIGURE 9: Voltage and current variations of PV modules.

It was observed that the maximum tested current was 8.6 $\mathrm{A}$ at $12: 35$. The output voltage changes were $50.8 \mathrm{~V}-54.2 \mathrm{~V}$ and the maximum voltage appears at 12:36. In batteries discharging, ice maker can be driven for 10 hours by batteries only which were in full power state and disconnected with PV modules until the batteries electricity decreased and cannot drive the ice maker. The voltage declined from $54.88 \mathrm{~V}$ to $44.6 \mathrm{~V}$ step by step and the output current of PV modules was approximately $7 \mathrm{~A}$ with small fluctuations between $5.4 \mathrm{~A}$ and $7.4 \mathrm{~A}$. In charging process for batteries, batteries disconnect with ice maker and connected with PV modules. Batteries current changed with solar irradiance and voltage increased gradually until batteries were in floating state.

Electricity conversed from light by distributed photovoltaic energy system was transferred among batteries, ice maker, and air conditioning system. It was very important to optimize and match the energy among PV modules, storage batteries, and power consumption machine, which can provide an important reference for the future work. Therefore, the experimental study on ISACS driven by DPES

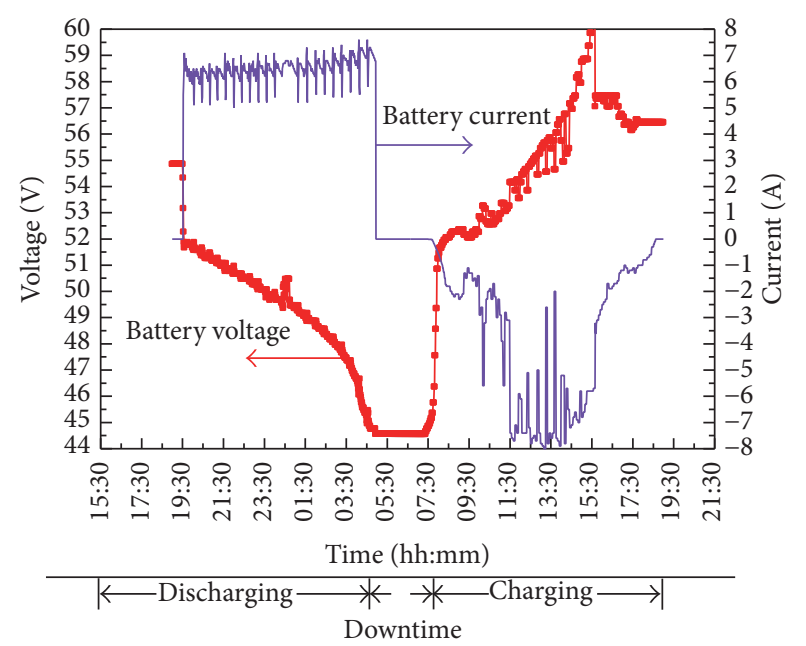

FIGURE 10: Voltage and current variations of batteries.

was carried out in order to analyze the light-electricity-cold conversion process and the energy transfer characteristics. The results are shown in Figure 11.

There were ice making and ice melting abscission in ice maker operation process. In ice making process, the system current was $1.8 \mathrm{~A}$, the sum of compressor working current and condenser fan current. However, in ice melting abscission process, the system current was $1.4 \mathrm{~A}$, the sum of condenser fan current and solenoid valve operating current. On the other hand, the voltage of AC compressor was $220 \mathrm{~V}$ and it was stable all the time. Voltage and current of pump and fan were $220 \mathrm{~V}$ and $0.4 \mathrm{~A}$ and $380 \mathrm{~V}$ and $0.5 \mathrm{~A}$, respectively. In DPES, photovoltaic modules and batteries were untied and used to drive ice maker. Before noon the PV modules output current increases along with solar irradiance and batteries output current gradually decreases. When PV modules output current increased to $6.5 \mathrm{~A}$, batteries output current reduced to $0 \mathrm{~A}$ at 10:50 and ice maker can be completely driven by PV modules. Since then, ice maker was driven by PV module and the rest electricity can be stored in batteries. Batteries charging current increased step by step and reached the maximum of $2.0 \mathrm{~A}$ until the solar irradiance reached the peak values at 12:20. After noon, batteries charging current gradually reduces along with solar irradiance decreases. It was found that at 15:37 the charging current and PV modules output current were $0 \mathrm{~A}$ and $6.5 \mathrm{~A}$. Therefore, ice maker was only driven by PV modules once again. Subsequently, the generated electricity by PV modules was not enough to drive the ice maker and batteries discharged to supplement the shortage. Batteries discharging current increases step by step along with the solar irradiance decreases. Batteries voltage reduced in discharging process and increased in charging process. Batteries separately derived pump and fan coil to supply cold from 19:00 to 23:00. Output current remained constant with $5 \mathrm{~A}$ and output voltage slightly decreased gradually. At 23:00, ice melts completely and then all machines were shut down. Until 07:30 of the next day, a new ice making and cold supplying cycle starts. Through the 27-hour experiment, batteries capacity decreased from $65 \mathrm{Ah}$ to $9.76 \mathrm{Ah}$ 


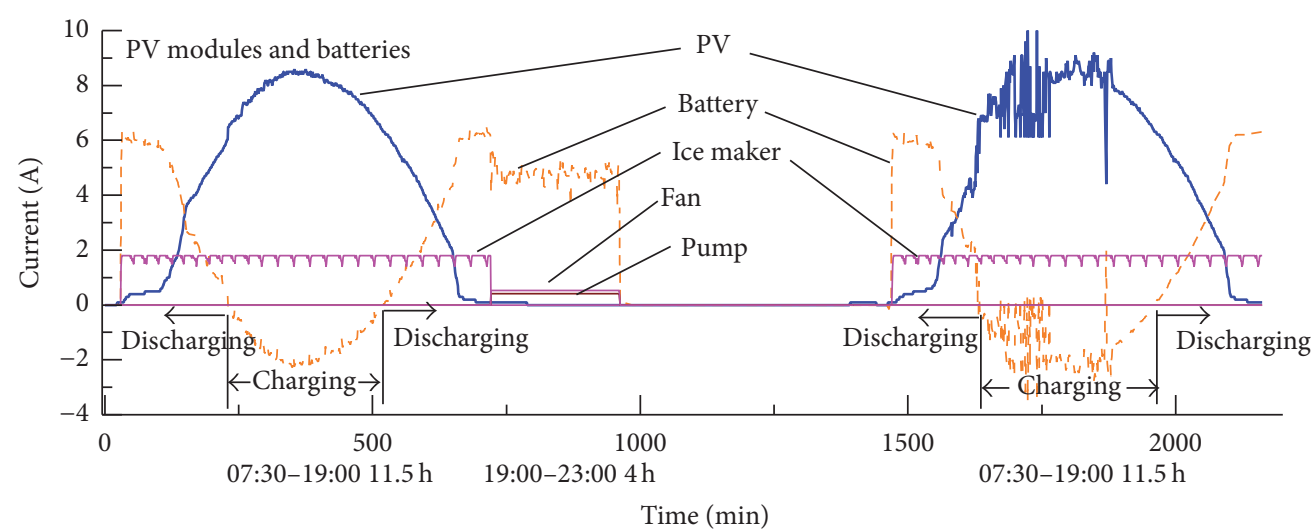

| Ice maker runs to produce ice $\left.\right|_{\nwarrow} \quad \nearrow \quad$ All machines stop $\quad \mid$ Ice maker runs to produce ice $\mid$ Pump and fan run to supply cold

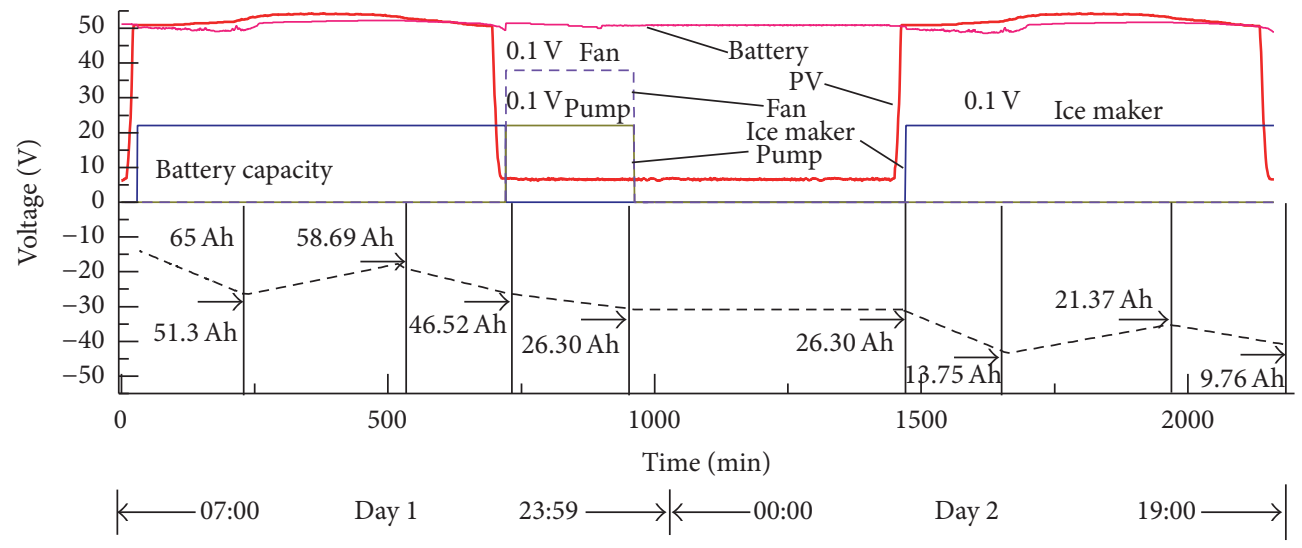

FIGURE 11: The conversion and flow characteristics of power generated by PV modules among batteries, ice maker, and air conditioning system.

with a 55.24 Ah decrease. In the first day, batteries discharged 13.7 $\mathrm{Ah}$ in the morning and then were charged $7.39 \mathrm{Ah}$ by PV modules. Batteries discharged 12.17 Ah from 15:37 to 19:00. And then ice maker stopped and cold exchanger ran, driven by batteries. The electricity consumption was $20.22 \mathrm{~A}$ from 19:00 to 23:00. In the next day, ice maker starts to work at 07:00 and electricity consumption in the morning discharging process and afternoon discharging process was $12.55 \mathrm{Ah}$ and $11.61 \mathrm{Ah}$, respectively. Batteries were charged 7.62 Ah by PV modules from 10:11 to 15:36.

\subsubsection{Ice Maker and Cold Storage System. The ice production} is shown in Figure 12.

It was found that the total amount of ice was $16.98 \mathrm{~kg}$. Ice maker operation cycle time was $10 \mathrm{~min}$ and the ice production was about $0.35 \sim 0.36 \mathrm{~kg}$ every cycle. Ice making efficiency was about $2.12 \mathrm{~kg} / \mathrm{h}$. Another experimental test has been conducted at various temperatures of ice maker with every component in thermodynamic cycle of ice making process, as shown in Figure 13. The inlet temperature and outlet temperature of evaporator, compressor, and condenser declined stably until ice making process was performed.

In ice making process, ice was pasted well together with five solid walls of grid plate evaporator and cannot be

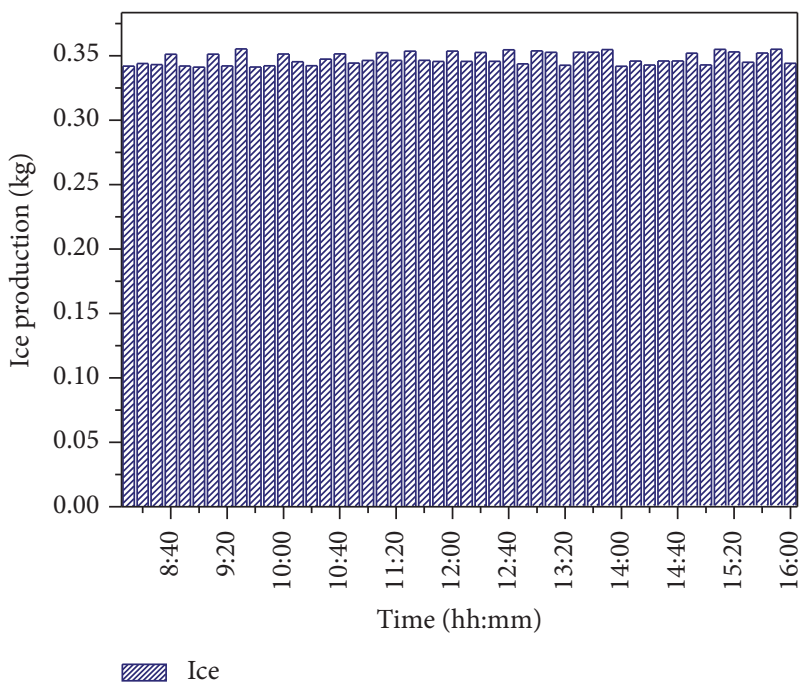

FIGURE 12: Ice production of ice maker driven by DPES from 8:00 to 16:00 on 22nd Nov., 2015, in Kunming.

separated off by ice gravity. Thus, compressor must be shut down and a special solenoid valve as shown in Figure 14 


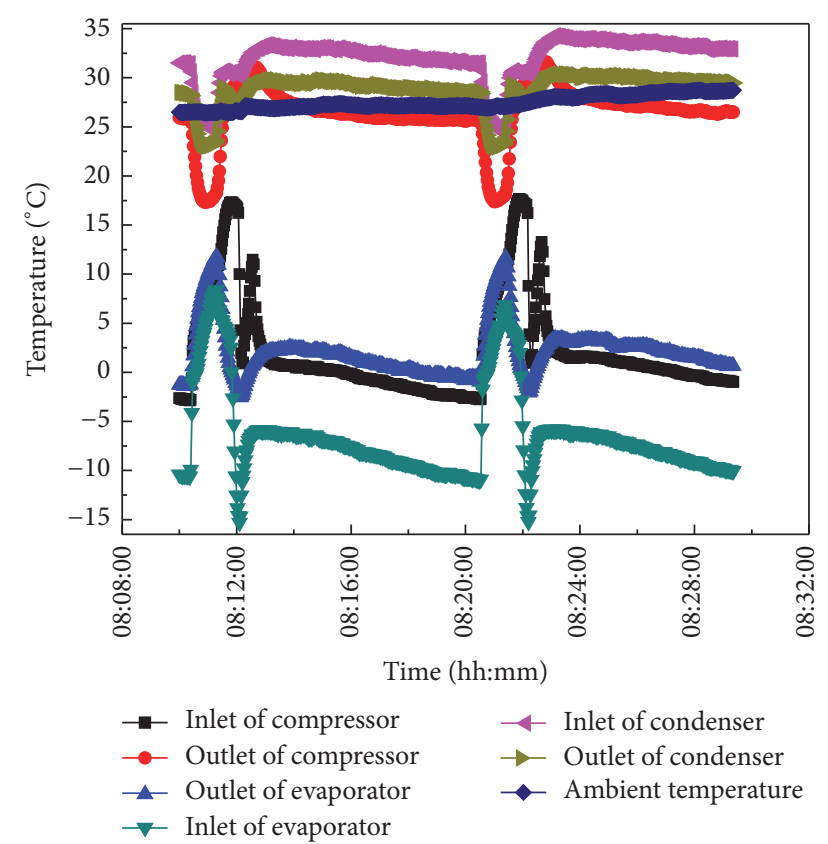

FIGURE 13: Temperature variations of ice maker components during two refrigeration thermodynamic cycle processes.

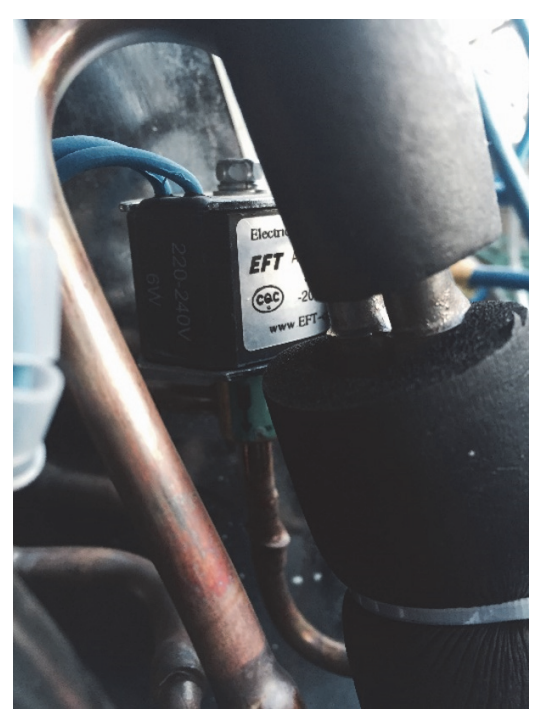

FIGURE 14: Electromagnetic valve photo adopted in ice maker system.

must be opened which was used for adjusting refrigerant flow and introduced the high temperature and high pressure refrigerant steam expelled from compressor into evaporator.

When the electromagnetic was opened, the evaporator plays the role of condenser to release heat to ice through solid walls and ice interfaces begin melting. Ice was divorced from evaporator and fell into tank. Meanwhile, evaporator inlet temperature and outlet temperature increased sharply until the solenoid valve was closed and compressor was turned on and a new ice making process begins. The refrigerant flowed out of evaporator into throttle valve and became low temperature and low pressure liquid. And then, the refrigerant flowed into condenser to absorb heat from outside and condenser inlet and outlet temperature declined sharply when low temperature refrigerant flowed into it. Condenser outlet temperature was higher than condenser inlet because refrigerant absorbed heat from outside through condenser, as shown in Figure 12. Refrigerant next flowed into compressor and compressor inlet temperature increased a lot compared to ice making process, which can be changed with inlet and outlet temperature variation of evaporator and condenser. Compressor stops running in ice melting abscission process and the refrigerant gas cannot be compressed in compressor. Therefore, the compressor outlet temperature drops sharply when the solenoid valve opens and it returns smoothly when ice making process opened. Ice melting abscission process was extremely unfavorable to ISACS for a number of reasons as follows:

(1) Ice maker operation period extended for $200 \mathrm{~s}$; furthermore, the ice melting abscission time was onethird time of an ice making cycle.

(2) Service life of compressor will be shortened by frequent start and stop compressor, which has a great impact on ice making process and was extremely unfavorable for energy supply process of DPES. Electricity consumption of solenoid valve was $3.0 \times$ $10^{-4} \mathrm{~kW} \mathrm{~h}$ in ice melting abscission process and the total electricity consumption was $0.024 \mathrm{kWh}$ from 7:30 to 19:00.

3.2.3. Air Conditioning System. The performance of air conditioning system was tested at 19:00. At this time, the temperature of ice stored in ice storage tank and ice storage tank temperature were $-3^{\circ} \mathrm{C}$ and $-1^{\circ} \mathrm{C}$, respectively. The indoor temperature was $20.5^{\circ} \mathrm{C}$. The changes of temperature for exchanging cold and supplying cold processes are shown in Figure 15.

Ice storage temperature remained constant at $-1^{\circ} \mathrm{C}$ in ice absorbing and melting phase transition processes. However, after 22:20, all ice melted and the tank filled with water at low temperature. Subsequently, the temperature of water gradually increased when the water was employed to cool. Subsequently, it increased from $0^{\circ} \mathrm{C}$ to nearly $5^{\circ} \mathrm{C}$ within $40 \mathrm{~min}$. At the end of the experiment, ice storage tank outlet temperature increased to $11.5^{\circ} \mathrm{C}$ from initial temperature of $3.4^{\circ} \mathrm{C}$. In ice phase transition process, ice storage tank inlet and outlet temperatures should be constant values in theory; however, the temperature difference between inlet and outlet increased $7.15^{\circ} \mathrm{C}$ mainly as a result of the working temperature of pipeline pump. It was found that the fan outlet temperature decreased from $20.5^{\circ} \mathrm{C}$ to $15.1^{\circ} \mathrm{C}$ with a $5.4^{\circ} \mathrm{C}$ decline and the indoor temperature decreased from $20.5^{\circ} \mathrm{C}$ to $18^{\circ} \mathrm{C}$ with a $2.5^{\circ} \mathrm{C}$ decline within 4 hours. Cold power blown out by fan coil was $0.298 \mathrm{~W}$ and the cold exchanging and supplying efficiency of the air conditioning system was 90.4\%. Furthermore, the ice storage tank has a good thermal insulation performance at $0.10 \mathrm{~m}$ thick polyurethane foam. The ice cold loss in ice storage tank was $218.59 \mathrm{~kJ}$ as $3.89 \%$ 


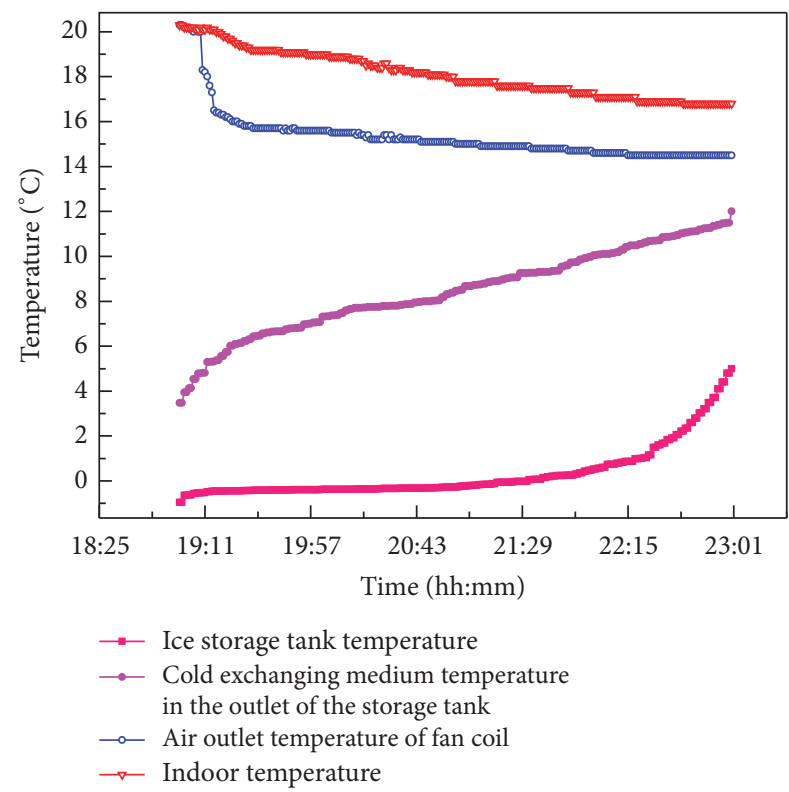

FIGURE 15: Temperatures change of exchanging cold and supplying cold process.

of input cold from 19:00 to 23:00 and the cold loss of fan coil was $313.92 \mathrm{~kJ}$ as $5.82 \%$ of input cold.

3.3. Model Validation. The system energy efficiency was $5.44 \%$ calculated as shown in Table 4 . In the experimental test process, the ice produce was 16.98 kg during 08:00 16:00 with the $22.17 \mathrm{MJ} / \mathrm{m}^{2}$ total irradiation. Because the ice maker was driven by PV modules and batteries, the ice produce was not only produced by $\mathrm{PV}$ modules. Therefore, the ice production of PV modules must be calculated. The rated power of ice maker was $380 \mathrm{~W}$ as shown in Table 1 which was not only made up with the power of compressor as shown in Table 3 but also included the powers of fan, solenoid valve, and water pump. The electricity consumption of ice maker was $3.04 \mathrm{~kW} \cdot \mathrm{h}$ during 08:00 16:00. But the electricity $Q$ produced by PV modules was only $2.76 \mathrm{~kW} \cdot \mathrm{h}$ as shown in Table 3 . So there was $90.79 \%$ power consumed by ice maker coming from PV modules. So the ice produced by PV modules was $15.42 \mathrm{~kg}$. The ice phase change latent heat was $335 \mathrm{~kJ} / \mathrm{kg}$. So the energy stored by ice produced by PV modules was $5165.70 \mathrm{~kJ}$. The total area of PV modules was $3.24 \mathrm{~m}^{2}$. So the total solar energy accepted by PV modules was $71830.80 \mathrm{~kJ}$. And the cold exchange efficiency of air conditioning system was $85.42 \%$ as shown in Table 4 . So the energy efficiency of ISACS driven by DPES tested in the experiment was 6.14\%. The relative error of the calculated result was $11.4 \%$. The model can be accepted in engineering application fields.

3.4. System Optimization. Analog computation and experimental tests results showed that there were some deficiencies of current system as follows:

(1) Usually the cold demand during the daytime is high, but the system can supply cold through ice melting made by ice maker driven by electricity generated by PV modules in daytime. Therefore, there is no matching between cold supply and demand in the same time.

(2) Energy loss is huge and ice making efficiency is low in ice making process of ice slide maker.

Therefore, in order to improve the performance of ISACS driven by DPES and promote the project commercial promotion, some optimization and improvement measurements were proposed as follows:

(a) Evaporator immersion static refrigeration mode was adopted to replace ice harvester refrigeration mode. The optimized coil evaporator was immersed into water to absorb heat and make ice and all the energy was utilized, as shown in Figure 16.

(b) The coil cold exchanger was cointegrated with coil evaporator. In refrigeration process, coil cold exchanger has the priority to get cold transferred from the coil evaporator next to the cold exchanger to supply cold for user. Surplus cold is used to make ice to store cold. Consequently, ISACS not only has the out-ofthe-box function of ordinary air conditioning, but also effectively improves the appearing phenomenon of overcooling and remedies the disadvantage of cold supply after ice making process in traditional submerged ice making system. The top view of cointegration evaporators and cold exchanger immersed in the ice storage tank is shown in Figure 17.

Another immersion static ice maker with evaporator cointegrated with coil cold exchanger was constructed according to the optimization design shown in Figure 18.

The performance of optimized ISACS driven by DPES can be tested and calculated as mentioned above. The system operated on May 12, 2016. The tested and calculated results were shown in Figure 19 and Table 5.

The water tank was full of $13.4 \mathrm{~kg}$ water. The system operated at 08:35 and all of the water changed into ice at about 10:40. And then the ice started subcooling and the ice surface became hard at 12:04. At the moment, the surface of evaporator temperature (the temperature of ice core) was $-12.11^{\circ} \mathrm{C}$ and the water temperature was $-8.09^{\circ} \mathrm{C}$ with a $4.20^{\circ} \mathrm{C}$ temperature difference between ice surface and ice core. At 12:04, the temperatures of evaporator inlet and outlet were, respectively, $-20.49^{\circ} \mathrm{C}$ and $-16.51^{\circ} \mathrm{C}$ and the compressor inlet temperature was $-14.28^{\circ} \mathrm{C}$. The energy efficiency and exergy efficiency of system components of optimized ISACS driven by DPES were calculated through above formulas and the performances of the system mentioned above and the optimized system were compared in Table 5.

By structure optimization, the ice making efficiency of evaporator immersion static ice maker was improved to $6.00 \mathrm{~kg} / \mathrm{h}$ which was 2.88 times of ice slide maker with the same input power. Through theoretical calculation, it was observed that the ice making efficiency and exergy efficiency increased from $17.38 \%$ to $50.12 \%$ and from $95.57 \%$ to $97.32 \%$, respectively. So the ice maker system energy efficiency was 

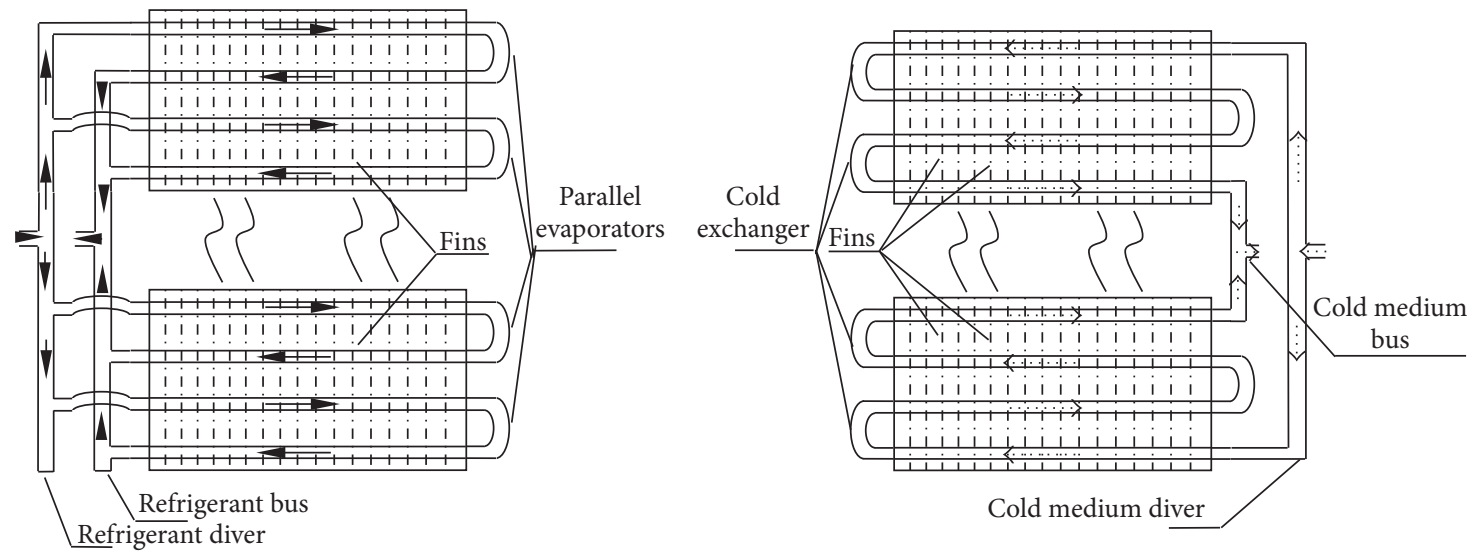

Figure 16: Profile of evaporators and cold exchanger immersed in the ice storage tank.
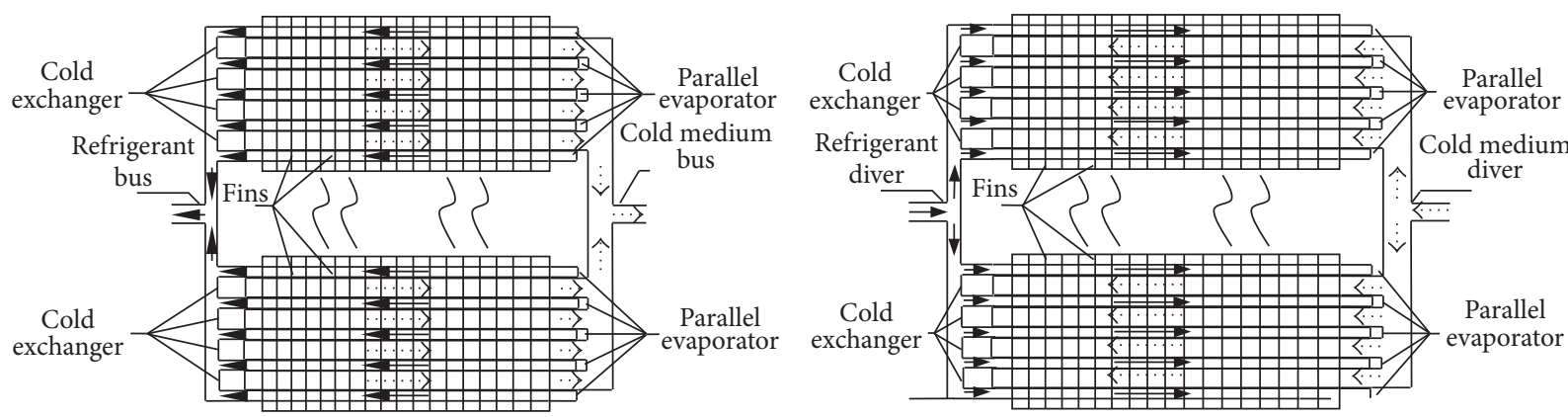

FIGURE 17: Top view of cointegration evaporators and cold exchanger immersed in the ice storage tank.

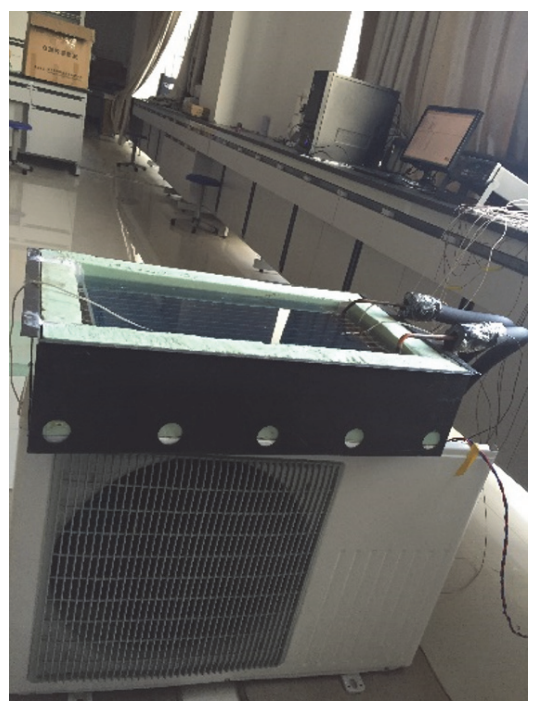

FIGURE 18: The photo of evaporator immersion static ice maker.

improved 2.88 times and exergy efficiency was improved from $76.85 \%$ to $78.52 \%$. After the structure optimization, the energy efficiency of ISACS driven by DPES can be improved from $5.44 \%$ to $15.69 \%$ and the exergy efficiency can be improved from $67.30 \%$ to $68.54 \%$. When evaporator

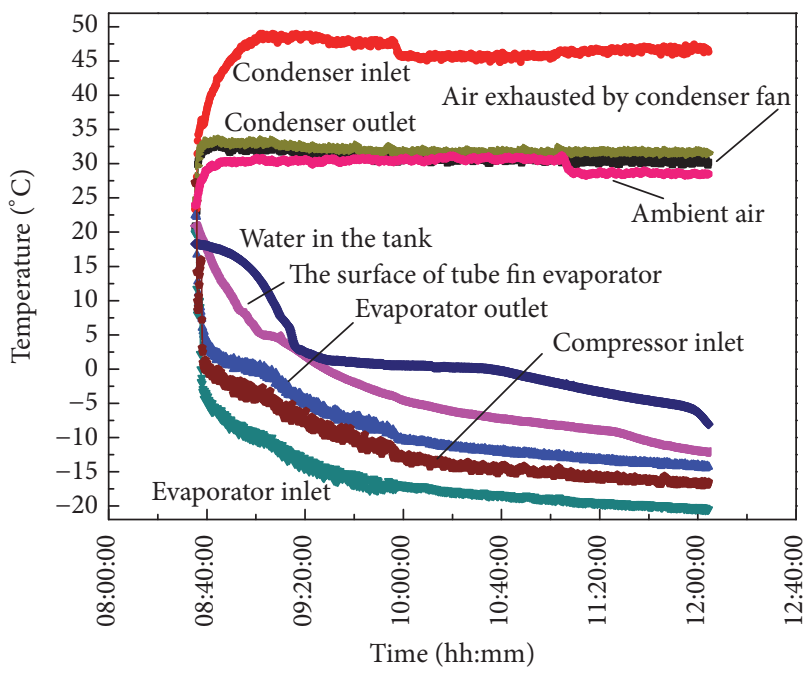

FIgURE 19: Temperature changes of ice maker components after optimization.

cointegrated with coil cold exchanger, ISACS achieved outof-box functionality as the ordinary vapor compression air conditioning system, which can effectively solve the problem of cold supplying process must lagging behind ice making process in traditional ice storage air conditioning system. 


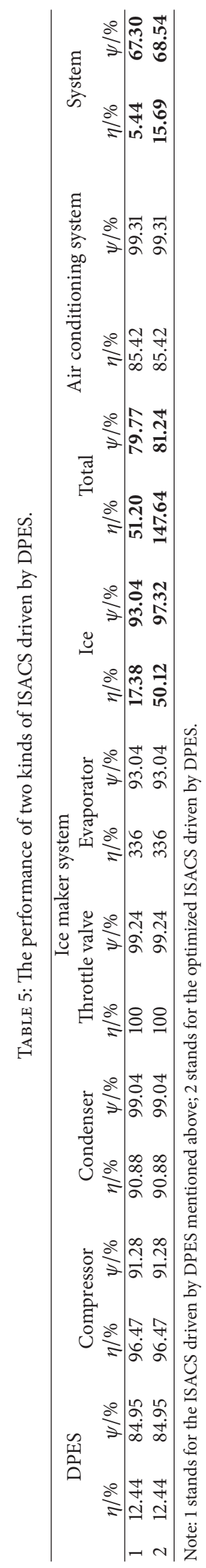




\section{Conclusions}

(1) The energy utilization ratio and exergy efficiency of ISACS driven by DPES were $5.44 \%$ and $67.30 \%$, respectively. DPES conversion efficiency was $12.44 \%$ with $84.95 \%$ exergy efficiency and ice maker system energy efficiency was $51.20 \%$ with $79.77 \%$ exergy efficiency.

(2) In order to improve the refrigeration performance of ISACS, evaporator immersion static refrigeration mode was adopted to replace ice harvester refrigeration mode to achieve high efficiency refrigeration.

(3) The coil cold exchanger was cointegrated with coil evaporator. Consequently, ISACS not only has the out-of-the-box function of ordinary air conditioning system, but also effectively improves the appearance of overcooling phenomenon.

(4) By simulation, the system energy utilization efficiency could be improved from $5.44 \%$ to $15.69 \%$ with exergy efficiency increasing from $67.30 \%$ to $68.54 \%$.

\section{Nomenclature}

Roman Symbols

$\begin{array}{ll}\mathrm{BC}: & \text { Batteries capacity }(\mathrm{Ah}) \\ C_{P}: & \text { Empirical constant } \\ C_{R}: & \text { Empirical constant } \\ C_{p}: & \text { Specific heat capacity }\left(\mathrm{J} \cdot \mathrm{kg}^{-1} \cdot \mathrm{K}^{-1}\right) \\ \Delta E: & \text { Exergy loss }(\mathrm{W}) \\ E: & \text { Exergy }(\mathrm{W}) \\ G: & \text { Solar irradiance }\left(\mathrm{W} \cdot \mathrm{m}^{-2}\right) \\ h: & \text { Enthalpy }\left(\mathrm{J} \cdot \mathrm{kg}^{-1}\right) \\ I: & \text { Current }(\mathrm{A}) \\ m: & \text { Mass }(\mathrm{kg}) \\ \dot{m}: & \text { Mass flow }\left(\mathrm{kg} \cdot \mathrm{s}^{-1}\right) \\ \mathrm{Q}: & \text { Power per unit time }(\mathrm{W}) \\ r_{1}, r_{2}, r_{3}, r_{4}: & \text { Empirical constants } \\ s: & \text { Entropy }\left(\mathrm{J} \cdot \mathrm{kg}^{-1} \cdot \mathrm{K}^{-1}\right) \\ S: & \text { Area }\left(\mathrm{m}^{2}\right) \\ t: & \text { Runtime }(\mathrm{s}) \\ T: & \text { Temperature }(\mathrm{K}) \\ V: & \text { Voltage }(\mathrm{V}) \\ \mathrm{VF}: & \text { Full charge rest voltage }(\mathrm{V}) \\ v: & \text { Speed }\left(\mathrm{m} \cdot \mathrm{s}^{-1}\right) \\ W: & \text { Compressor operating power }(\mathrm{W}) .\end{array}$

\section{Greek Symbols}

$\alpha$ : Solar cell absorption coefficient

$\tau$ : PV module cover glass transmittance

$\xi$ : Symbolic coefficient

$\eta$ : Energy efficiency

$\psi$ : Exergy efficiency.

\section{Subscripts}

1: Refrigerant in state 1

2: Refrigerant in state 2

\begin{tabular}{|c|c|}
\hline 3: & Refrigerant in state 3 \\
\hline 4: & Refrigerant in state 4 \\
\hline 5: & Refrigerant in state 5 \\
\hline$a:$ & Ambient \\
\hline air: & Indoor air \\
\hline $\mathrm{AB}:$ & Evaporator absorption \\
\hline$B:$ & Batteries \\
\hline$c:$ & Cell \\
\hline Conv: & Convective \\
\hline$C:$ & Controller \\
\hline CP: & Compressor \\
\hline CO: & Condenser \\
\hline elect: & Electricity \\
\hline$E:$ & Emission \\
\hline $\mathrm{EV}:$ & Evaporator \\
\hline icemk: & Ice maker \\
\hline fancoil: & Fan coil \\
\hline in: & Input \\
\hline$I:$ & Inverter \\
\hline ice: & Ice \\
\hline loss: & Loss \\
\hline$m:$ & Maximum power point \\
\hline oc: & Open circuit \\
\hline out: & Output \\
\hline$p:$ & Parallel \\
\hline PV: & PV modules \\
\hline rf: & Refrigeration \\
\hline$s:$ & Sky \\
\hline sc: & Short circuit \\
\hline sun: & Sun \\
\hline storage: & Storage \\
\hline TH: & Throttle valve. \\
\hline
\end{tabular}

\section{Competing Interests}

The authors declare that they have no competing interests.

\section{Acknowledgments}

The authors gratefully acknowledge the financial support provided by National Natural Science Foundation of China (51666018) and National International Scientific and Technological Cooperation Program (2011DFA62380). The authors are also grateful to Renewable Energy Research and Innovation Development Center in Southwest China (05300205020516009), Research and Innovation Team of Renewable Energy in Yunnan Province and Yunnan Provincial Renewable Energy Engineer Key Laboratory (2015KF05), and Yunnan Provincial Department of Education Science Research Fund Project (2015J035).

\section{References}

[1] A. Allouhi, T. Kousksou, A. Jamil, P. Bruel, Y. Mourad, and Y. Zeraouli, "Solar driven cooling systems: an updated review," Renewable and Sustainable Energy Reviews, vol. 44, pp. 159-181, 2015.

[2] A. Ghafoor and A. Munir, "Worldwide overview of solar thermal cooling technologies," Renewable and Sustainable Energy Reviews, vol. 43, pp. 763-774, 2015. 
[3] N. M. Khattab, H. Sharawy, and M. Helmy, "Development of vovel solar adsorption cooling tube," Energy Procedia, vol. 18, pp. 709-714, 2012.

[4] D. Attan, M. A. Alghoul, B. B. Saha, J. Assadeq, and K. Sopian, "The role of activated carbon fiber in adsorption cooling cycles," Renewable and Sustainable Energy Reviews, vol. 15, no. 3, pp. 1708-1721, 2011.

[5] S. Du, R. Z. Wang, and Z. Z. Xia, "Graphical analysis on internal heat recovery of a single stage ammonia-water absorption refrigeration system," Energy, vol. 80, pp. 687-694, 2015.

[6] Q. W. Pan, R. Z. Wang, Z. S. Lu, and L. W. Wang, "Experimental investigation of an adsorption refrigeration prototype with the working pair of composite adsorbent-ammonia," Applied Thermal Engineering, vol. 72, no. 2, pp. 275-282, 2014.

[7] Z. Y. Xu and R. Z. Wang, "Experimental verification of the variable effect absorption refrigeration cycle," Energy, vol. 77, pp. 703-709, 2014.

[8] S. Du, R. Z. Wang, and Z. Z. Xia, "Optimal ammonia water absorption refrigeration cycle with maximum internal heat recovery derived from pinch technology," Energy, vol. 68, pp. 862-869, 2014.

[9] L. Jiang, L. W. Wang, and R. Z. Wang, "Investigation on thermal conductive consolidated composite $\mathrm{CaCl}_{2}$ for adsorption refrigeration," International Journal of Thermal Sciences, vol. 81, no. 1, pp. 68-75, 2014.

[10] X. Ji, M. Li, J. Fan, P. Zhang, B. Luo, and L. Wang, "Structure optimization and performance experiments of a solar-powered finned-tube adsorption refrigeration system," Applied Energy, vol. 113, pp. 1293-1300, 2014.

[11] Y. J. Dai, R. Z. Wang, and L. Ni, "Experimental investigation and analysis on a thermoelectric refrigerator driven by solar cells," Solar Energy Materials \& Solar Cells, vol. 77, no. 4, pp. 377-391, 2003.

[12] M. A. Aktacir, "Experimental study of a multi-purpose PVrefrigerator system," International Journal of Physical Sciences, vol. 6, no. 4, pp. 746-757, 2011.

[13] E. F. Mba, J. L. Chukwuneke, and C. H. Achebe, "Modeling and simulation of a photo-voltaic Powered vapor compression refrigeration system," Journal of Information Engineering and Applications, vol. 2, pp. 1-15, 2012.

[14] G. M. Tina and A. D. Grasso, "Remote monitoring system for stand-alone photovoltaic power plants: the case study of a PV-powered outdoor refrigerator," Energy Conversion and Management, vol. 78, pp. 862-871, 2014.

[15] M. Bilgili, "Hourly simulation and performance of solar electric-vapor compression refrigeration system," Solar Energy, vol. 85, no. 11, pp. 2720-2731, 2011.

[16] S. Kaplanis and N. Papanastasiou, "The study and performance of a modified conventional refrigerator to serve as a $\mathrm{PV}$ powered one," Renewable Energy, vol. 31, no. 6, pp. 771-780, 2006.

[17] O. Ekren, A. Yilanci, E. Cetin, and H. K. Ozturk, "Experimental performance evaluation of a PV-powered refrigeration system," Elektronika ir Elektrotechnika, vol. 114, no. 8, pp. 7-10, 2011.

[18] A. Modi, A. Chaudhuri, B. Vijay, and J. Mathur, "Performance analysis of a solar photovoltaic operated domestic refrigerator," Applied Energy, vol. 86, no. 12, pp. 2583-2591, 2009.

[19] P. J. Axaopoulos and M. P. Theodoridis, "Design and experimental performance of a PV Ice-maker without battery," Solar Energy, vol. 83, no. 8, pp. 1360-1369, 2009.

[20] E. F. Robert, E. A. Luis, and B. David, "Photovoltaic direct drive refrigerator with ice storage: preliminary monitoring results," in Proceedings of the ISES Solar World Congress, Adelaide, Australia, 2001.

[21] J. Pu, G. Liu, and X. Feng, "Cumulative exergy analysis of ice thermal storage air conditioning system," Applied Energy, vol. 93, pp. 564-569, 2012.

[22] M. Navidbakhsh, A. Shirazi, and S. Sanaye, "Four E analysis and multi-objective optimization of an ice storage system incorporating PCM as the partial cold storage for air-conditioning applications," Applied Thermal Engineering, vol. 58, no. 1-2, pp. 30-41, 2013.

[23] S. Sanaye and A. Shirazi, "Thermo-economic optimization of an ice thermal energy storage system for air-conditioning applications," Energy and Buildings, vol. 60, pp. 100-109, 2013.

[24] Y. Han, B. Shen, H. Hu, and F. Fan, "Optimizing the performance of ice-storage systems in electricity load management through a credit mechanism: an analytical work for Jiangsu, China," Energy Procedia, vol. 61, pp. 2876-2879, 2014.

[25] X. Wang and M. Dennis, "Influencing factors on the energy saving performance of battery storage and phase change cold storage in a PV cooling system," Energy and Buildings, vol. 107, pp. 84-92, 2015.

[26] Y. Li, S. Zhou, W. Lin, X. Ji, X. Luo, and M. Li, "Performance analysis of photovoltaic refrigerator system," Acta Energiae Solaris Sinica, vol. 36, no. 2, pp. 422-429, 2015.

[27] O. Ekren, S. Celik, B. Noble, and R. Krauss, "Performance evaluation of a variable speed DC compressor," International Journal of Refrigeration, vol. 36, no. 3, pp. 745-757, 2013.

[28] Y. Sukamongkol, S. Chungpaibulpatana, and W. Ongsakul, "A simulation model for predicting the performance of a solar photovoltaic system with alternating current loads," Renewable Energy, vol. 27, no. 2, pp. 237-258, 2002. 

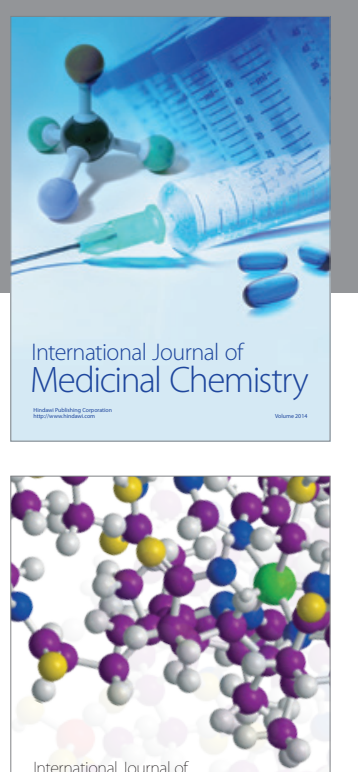

Carbohydrate Chemistry

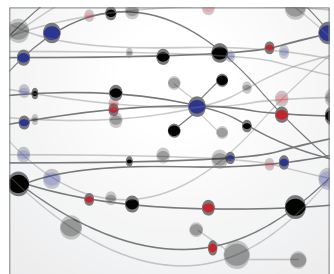

The Scientific World Journal
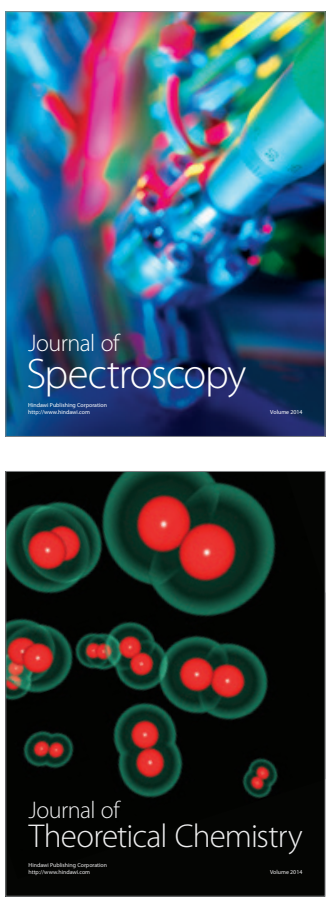
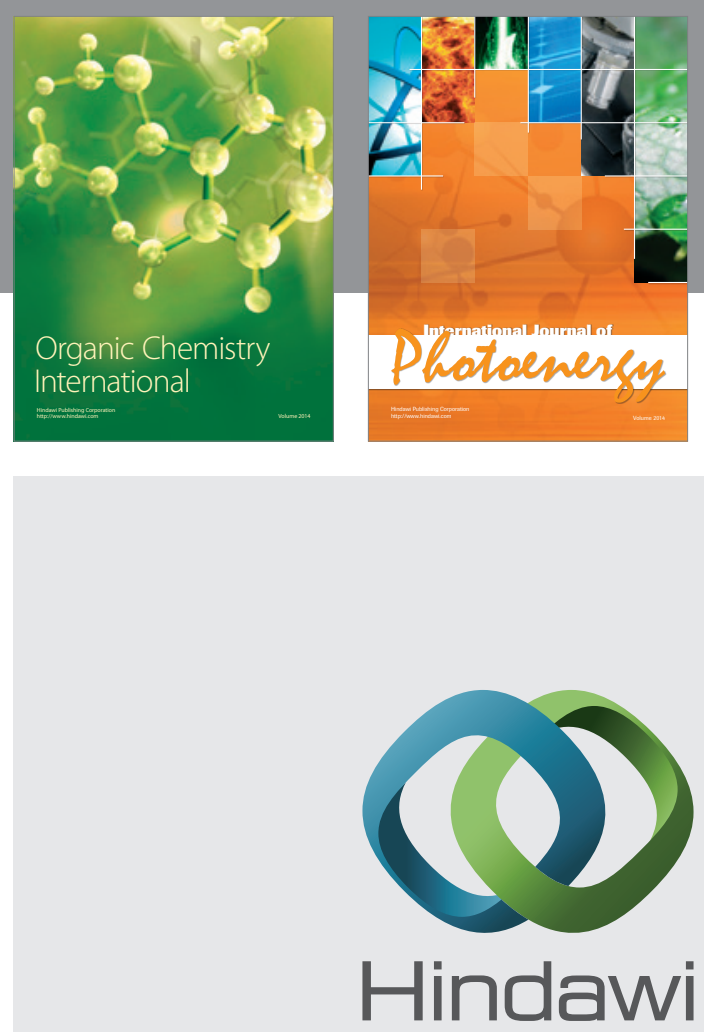

Submit your manuscripts at

http://www.hindawi.com

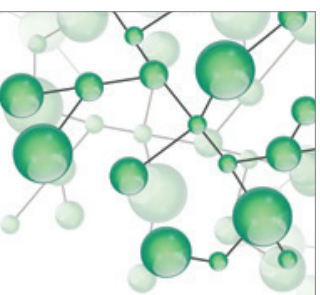

International Journal of

Inorganic Chemistry

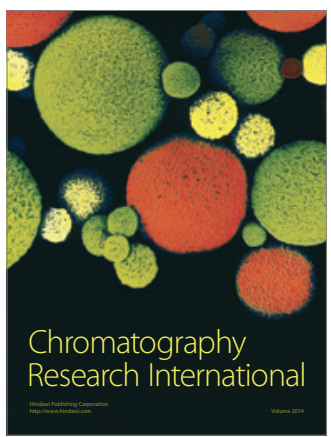

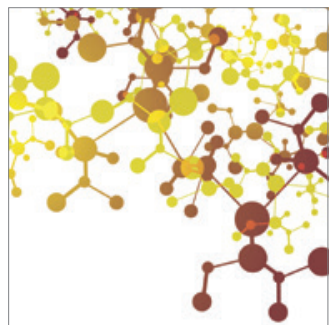

Applied Chemistry
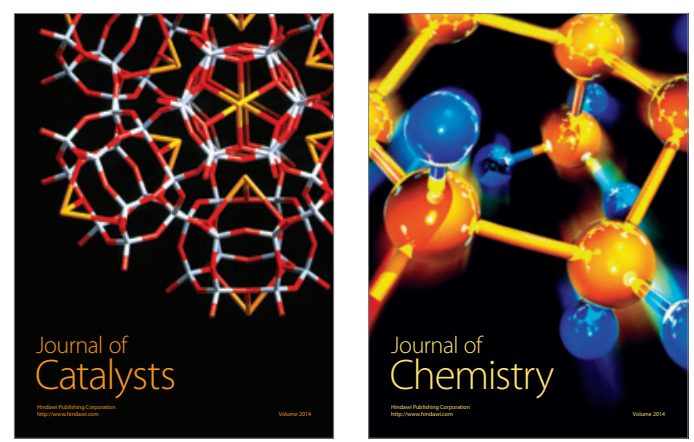
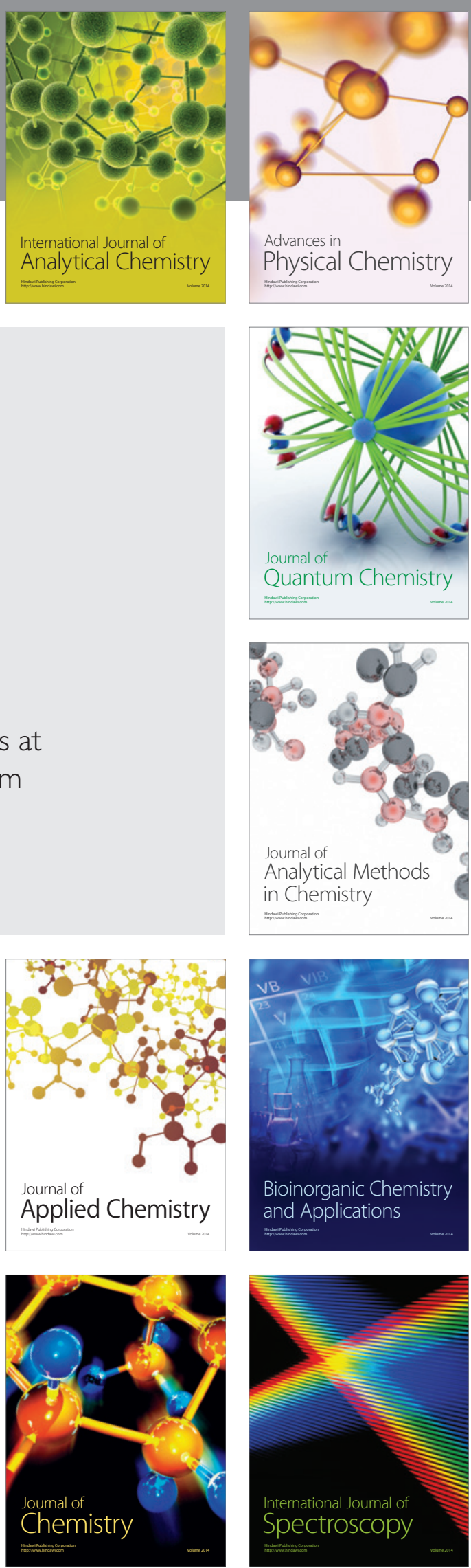